\title{
Amyloid precursor protein selective gamma- secretase inhibitors for treatment of Alzheimer's disease
}

Guriqbal S Basi ${ }^{1,2^{*}}$, Susanna Hemphill', Elizabeth F Brigham ${ }^{1}$, Anna Liao ${ }^{1}$, Danielle L Aubele ${ }^{1}$, Jeanne Baker ${ }^{1}$, Robin Barbour ${ }^{1,2}$, Michael Bova', Xiao-Hua Chen', Michael S Dappen ${ }^{1}$, Tovah Eichenbaum¹, Erich Goldbach', Jon Hawkinson ${ }^{1}$, Rose Lawler-Herbold ${ }^{1}$, Kang Hu${ }^{1}$, Terence Hui ${ }^{1}$, Jacek J Jagodzinski ${ }^{1}$, Pamela S Keim', Dora Kholodenko', Lee H Latimer', Mike Lee', Jennifer Marugg', Matthew N Mattson', Scott McCauley', James L Miller ${ }^{1}$, Ruth Motter ${ }^{1}$, Linda Mutter ${ }^{1}$, Martin L Neitzel' ${ }^{1}$, Huifang Ni', Lan Nguyen ${ }^{1}$, Kevin Quinn', Lany Ruslim', Christopher M Semko', Paul Shapiro', Jenifer Smith', Ferdie Soriano', Balazs Szoke', Kevin Tanaka', Pearl Tang', John A Tucker', Xiacong Michael Ye', Mei Yu', Jing Wu', Ying-zi Xu', Albert W Garofalo', John Michael Sauer ${ }^{1}$, Andrei W Konradi', Daniel Ness', George Shopp', Michael A Pleiss', Stephen B Freedman', Dale Schenk ${ }^{1,2}$

\begin{abstract}
Introduction: Inhibition of gamma-secretase presents a direct target for lowering $A \beta$ production in the brain as a therapy for Alzheimer's disease (AD). However, gamma-secretase is known to process multiple substrates in addition to amyloid precursor protein (APP), most notably Notch, which has limited clinical development of inhibitors targeting this enzyme. It has been postulated that APP substrate selective inhibitors of gamma-secretase would be preferable to non-selective inhibitors from a safety perspective for AD therapy.

Methods: In vitro assays monitoring inhibitor potencies at APP $\gamma$-site cleavage (equivalent to A $\beta 40$ ), and Notch $\varepsilon^{-}$ site cleavage, in conjunction with a single cell assay to simultaneously monitor selectivity for inhibition of $A \beta$ production vs. Notch signaling were developed to discover APP selective gamma-secretase inhibitors. In vivo efficacy for acute reduction of brain A $\beta$ was determined in the PDAPP transgene model of AD, as well as in wildtype FVB strain mice. In vivo selectivity was determined following seven days $x$ twice per day (b.i.d.) treatment with $15 \mathrm{mg} / \mathrm{kg} /$ dose to $1,000 \mathrm{mg} / \mathrm{kg} / \mathrm{dose}$ ELN475516, and monitoring brain A $\beta$ reduction vs. Notch signaling endpoints in periphery.

Results: The APP selective gamma-secretase inhibitors ELN318463 and ELN475516 reported here behave as classic gamma-secretase inhibitors, demonstrate 75- to 120-fold selectivity for inhibiting A $\beta$ production compared with Notch signaling in cells, and displace an active site directed inhibitor at very high concentrations only in the presence of substrate. ELN318463 demonstrated discordant efficacy for reduction of brain A $\beta$ in the PDAPP compared with wild-type FVB, not observed with ELN475516. Improved in vivo safety of ELN475516 was demonstrated in the $7 \mathrm{~d}$ repeat dose study in wild-type mice, where a 33\% reduction of brain $A \beta$ was observed in mice terminated three hours post last dose at the lowest dose of inhibitor tested. No overt in-life or post-mortem indications of systemic toxicity, nor RNA and histological end-points indicative of toxicity attributable to inhibition of Notch signaling were observed at any dose tested.
\end{abstract}

\footnotetext{
*Correspondence: guriq.basi@neotopebio.com

'Elan Pharmaceuticals, Inc. 180 Oyster Point Blvd., S. San Francisco, CA 94080, USA

Full list of author information is available at the end of the article
}

\section{() Biomed Central}

(C) 2010 Basi et al.; licensee BioMed Central Ltd. This is an open access article distributed under the terms of the Creative Commons Attribution License (http://creativecommons.org/licenses/by/2.0), which permits unrestricted use, distribution, and reproduction in any medium, provided the original work is properly cited. 
Conclusions: The discordant in vivo activity of ELN318463 suggests that the potency of gamma-secretase inhibitors in AD transgenic mice should be corroborated in wild-type mice. The discovery of ELN475516 demonstrates that it is possible to develop APP selective gamma-secretase inhibitors with potential for treatment for AD.

\section{Introduction}

The principal pathological features of Alzheimer's disease (AD), comprised of neurofibrilary tangles and amyloid plaques, are posited by the amyloid cascade hypothesis [1-3] to be pivotal in the clinical manifestations (impaired memory and cognition, dementia) of the disease. Current marketed therapies for AD offer palliative cognitive benefits with little to no impact on the underlying pathology, or on long-term disease progression. Effective treatments for $\mathrm{AD}$ that address the underlying disease represent a major unmet medical need.

Immunotherapy targeting $A \beta$ has been demonstrated to modify amyloid $[4,5]$ as well as tau related endpoints $[6,7]$ of AD pathology in pre-clinical models, as well as human clinical trials, and is currently in advanced clinical trials for potential treatment of mild to moderate $\mathrm{AD}[8,9]$. Orally bioavailable small molecule therapeutics offer the desirable attributes of convenient administration combined with in-home use for chronic therapy of $A D$, and as such, are anticipated to fill an unmet need in the emerging landscape of next generation $\mathrm{AD}$ therapeutics.

Pharmacological inhibition of gamma-secretase in vivo is a well-documented small molecule target for lowering brain, CSF, and plasma $\mathrm{A} \beta$ peptide [10-18], and impacting AD pathology [14,19-22]. Gamma-secretase inhibitors (GSIs) have also shown benefits on presumed correlates of memory in AD transgene models under acute [23], as well as, chronic treatment paradigms [24]. Consequently, gamma-secretase has been the target of ongoing medicinal chemistry efforts to discover therapeutics for treatment of AD [25-27]. However, inhibition of Notch processing by non-selective GSI's manifests in dysregulated cellular homeostasis and non-target organ side effects, for example, goblet cell hyperplasia in the gastrointestinal tract [28-30], that translate to clinical observations [31-33], and present challenges for clinical development of first generation GSI's [34]. Support for the observation that pharmacological effects of GSI's on cellular homeostasis in the gastro-intestinal tract are due to dysregulation of Notch pathway derives from observations with genetic knock-out [35-38] as well as gain of function mouse models [39] of Notch pathway genes.

Approaches to managing gastro-intestinal side effects of first generation GSIs via intermittent dosing [40,41] or glucocorticoid therapy [42] have been demonstrated in pre-clinical models. Additional efforts targeting gamma-secretase for AD therapy have been influenced by gamma-secretase cleavage site modulating properties of certain NSAIDS [43-45], and APP substrate selective/ Notch sparing GSIs (this report, [46-48]) as a means toward mitigating inhibition of Notch signaling. Clinical development of the most advanced NSAID based gamma-secretase modulator, tarenflurbil, was discontinued due to lack of efficacy in P3 clinical trial $[49,50]$, however, second generation candidates are progressing through both clinical [51] as well as preclinical stages of development [52-55]. Additionally, a nucleotide binding site on presenilin has also been reported to inhibit $A \beta$ while sparing Notch [56-58], and offers another avenue under investigation for the next generation of gammasecretase inhibitors.

The pharmacological and genetic evidence cited above validate gamma-secretase as a target for lowering $A \beta$ production as well as non-target organ side effects due to inhibition of Notch signaling. Together, the observations support the hypothesis that APP selective gamma-secretase inhibitors offer one approach toward potentially safer gamma secretase targeted therapeutics for AD. Toward that end, we report here the discovery of novel APP selective inhibitors of gamma-secretase discovered from a high throughput screen of a chemical library enabled by novel assays for comparing APP and Notch cleavage by gamma-secretase. We confirmed that the improved in vitro selectivity of our lead compound, ELN475516 translates into improved in vivo safety in a mouse model that is sensitive to histological and molecular end-points associated with inhibition of Notch signaling.

\section{Materials and methods Compounds}

ELN46719 is the 2-hydroxy-valeric acid amide analog of LY411575 (where LY411575 is the 3,5-difluoro-mandelic acid amide) (US Patent No 6,541,466). ELN318463 was described by Zhao et al. [59], and ELN475516 has been described as compound 11a by Mattson et al. [60].

\section{Antibodies and substrates}

Notch intracellular domain (NICD) neo-epitope monoclonal antibody (mAb) 9F3 was generated by immunizing mice with VLLSRGGC (corresponding to amino-terminus of human NICD, residues 1755 to 1759 in full length Notch) coupled to maleimide activated sheep anti-mouse 
IgG. Spleenocytes from the highest antibody titer mouse were fused with mouse myeloma cells. Hybridomas were screened against VLLSRGGC and counter screened against GCGVLLSR. Monoclonal antibody 9F3 only recognized VLLSRGGC peptide. The specificity of 9F3 for recognition of the amino-terminal neoepitope of NICD product, revealed from in vitro digestion of Notch $\Delta \mathrm{E}$ substrate by gamma-secretase enzyme, but not the uncleaved Notch $\Delta$ E substrate, was confirmed by Western blot assay. The sequence of this epitope is conserved between human and mouse Notch1.

E. coli expressed MBP-APPc125sw fusion protein substrate [61], was purified by amylose affinity chromatography per manufacturer's protocol (New England Biolabs, Ipswich, Massachusetts, USA) and stored at $-40^{\circ} \mathrm{C}$ as $2 \mathrm{mg} / \mathrm{mL}$ stock in $3 \mathrm{M}$ guanidine- $\mathrm{HCl}, 1 \%$ Triton-X100, $20 \mathrm{mM}$ Tris, (pH 7.5) until use.

Notch $\triangle E \Delta C$ substrate: A Notch fusion protein was constructed so as to be analogous to the APP C99 fragment as described [62]. Specifically, the Notch fusion protein is comprised of 99 amino-acids flanking the trans-membrane domain of mouse Notch1, accession (Genbank: Z11886). The amino-terminus of the fusion protein begins at residue \#1711 of mouse Notch (numbered from initiator methionine residue), and extends carboxy-terminal to residue \#1809, followed by in-frame fusion with HA epitope tag and six histidine residues prior to the stop codon. The two carboxy-terminal epitope tags are separated by an "LE" di-peptide spacer. The epitope tags were incorporated to facilitate ELISA detection of the NICD cleavage product using anti-HA antibody, and purification of the fusion protein substrate from E.coli lysates using nickel column affinity chromatography, respectively. Following overnight expression of the fusion protein in E.coli, the substrate is purified on a nickel-sepharose column from lysates. Purity of the $16 \mathrm{kD}$ Notch fusion protein substrate eluted from the nickel-affinity column is confirmed by SDS-PAGE. Fractions containing the desired protein were pooled, adjusted to 0.5 to $0.6 \mathrm{mg} / \mathrm{mL}$ final concentration in $3 \mathrm{M}$ Guanidine- $\mathrm{HCl}$, $0.1 \%$ Triton X-100 with $20 \mathrm{mM}$ DTT, and stored at $-80^{\circ} \mathrm{C}$ in aliquots until use in the enzyme reaction. This protein is not stable over long periods, and will aggregate even in the above storage buffer at $-80^{\circ} \mathrm{C}$. Hence, a new batch is prepared every three months to ensure assay quality. The substrate is desalted over a NAP-25 column immediately prior to use, protein concentration is determined by BCA assay (Pierce, Rockford, Illinois, USA), and diluted 20X for incubation with enzyme.

NICD ELISA standard: A human NICD standard was produced as a fusion protein from a construct in the bacterial expression vector pCal-kc (Invitrogen,
Carlsbad, California, USA). The expression construct was modified to encode an initiating methionine followed by an enterokinase cleavage at the N-terminus, fused in frame to the gamma-secretase product NICD (Met-EK-NICD, where NICD comprises residues 1755 to 1875 of human Notch1, numbering from the initiator methionine), an 8 residue spacer comprising the sequence PAAAAAA, and an HA epitope tag fused in frame with vector derived kemptide peptide, thrombin cleavage site and carboxy-terminal calmodulin binding peptide. The fusion protein was produced in E.coli, affinity purified using a calmodulin affinity resin and assayed for protein concentration. The protein was then cleaved with enterokinase in order to produce the free $\mathrm{N}$-terminus of the NICD product. The enterokinase cleaved protein was separated by SDS-PAGE on a $12 \%$ Tris-glycine gel. Enterokinase cleavage products are detected by Western blotting using an antibody against the HA-tag. Densitometry was used to measure the efficiency of the enterokinase cleavage. The estimated concentration of enterokinase cleaved NICD standard is calculated (\% of NICD/total HA-reactive protein). The standard was stored at $-40^{\circ} \mathrm{C}$. On the day of each assay, an aliquot of the NICD standard is serially diluted 1:1 in casein diluent to generate a standard curve with 0 to $200 \mathrm{ng} / \mathrm{mL}$ NICD.

\section{Enzyme preparation and in vitro assays for recombinant APP and Notch substrate cleavage}

An enriched detergent solubilized gamma-secretase enzyme preparation from IMR-32 neuroblastoma cells was obtained by membrane fractionation of crude homogenates using ultracentrifugation, followed by lectin affinity chromatography. Briefly, a 100,000 g membrane pellet of post nuclear superantant from IMR32 frozen cell pellets was homogenized in buffer $(250 \mathrm{mM}$ sucrose, $10 \mathrm{mM}$ HEPES (pH 7.5), $1 \mathrm{mM} \mathrm{MgCl}_{2}, 0.2 \mathrm{mM}$ $\mathrm{CaCl}_{2}+$ protease inhibitors, $5 \mathrm{~mL} / \mathrm{g}$ cell pellet), resuspended in an equal volume of hypotonic buffer (homogenization buffer minus sucrose), subjected to freeze thaw (dry-ice, $37^{\circ} \mathrm{C}$ water bath), and re-centrifuged at $100,000 \mathrm{x} \mathrm{g}$ for 20 minutes at $4^{\circ} \mathrm{C}$. The membrane pellet was snap frozen on dry ice, and stored at $-80^{\circ} \mathrm{C}$ until extraction. Thawed membranes were washed in $1 \mathrm{M}$ carbonate buffer $\left(1 \mathrm{M} \mathrm{Na}_{2} \mathrm{CO}_{3}, 1 \mathrm{mM} \mathrm{MgCl} 2,0.2 \mathrm{mM}\right.$ $\mathrm{CaCl}_{2}$ ) at $4^{\circ} \mathrm{C}$ for 15 minutes, centrifuged 100,000 X g as explained above, and resuspended in hypotonic wash buffer. Washed membrane pellets were resuspended in $0.5 \mathrm{X}$ final volume of solubilization buffer (10 mM CHES $\mathrm{pH}$ 9.5, $50 \mathrm{mM} \mathrm{NaCl}, 1 \mathrm{mM} \mathrm{MgCl}_{2}, 0.2 \mathrm{mM} \mathrm{CaCl}_{2}+$ protease inhibitors, minus pepstatin) and extracted in detergent containing $1.49 \mathrm{mg} / \mathrm{mL}$ BigCHAP (ICN), diluted fresh 1:10 from 50X stock $\left(149 \mathrm{mg} / \mathrm{mL}\right.$ in $\left.\mathrm{H}_{2} \mathrm{O}\right)$, at $4^{\circ} \mathrm{C}$ for $1.5 \mathrm{~h}$. Detergent extracts were centrifuged at 
$100,000 \times \mathrm{g}$ as explained above, and supernatant containing solubilized gamma-secretase aspirated for WGA chromatography. Peak eluate fractions were combined, and stored in $10 \mathrm{mM}$ Hepes, $\mathrm{pH}$ 7.5, $1 \mathrm{M} \mathrm{N}$-acetyl-Dglucosamine, $1 \mathrm{mM} \mathrm{MgCl}$, $0.2 \mathrm{mM} \mathrm{CaCl} 2,0.6 \mathrm{mg} / \mathrm{mL}$ TypeV brain extract (Sigma, St. Louis, Missouri, USA), $5.6 \mathrm{mg} / \mathrm{mL}$ BigCHAP.

\section{In vitro assay for cleavage of recombinant fusion protein substrates by partially purified gamma-secretase enzyme from IMR-32 cells}

The in vitro gamma-secretase assay was designed to measure the specific proteolytic cleavage of an APP substrate (MBP-APPc125Sw fusion protein) at the $A \beta 40$ site, or cleavage of Notch fusion protein at the Notch $\varepsilon$-site (corresponding to N-terminus of NICD). The substrates were incubated in separate reactions, in triplicate, with an enriched preparation of the enzyme from IMR32 cells, and the amount of specific product formed was measured using a sandwich ELISA comprised of an A 340 -specific capture antibody, 2G3, and a biotinylated A $317-28$ reporter antibody, $6 \mathrm{H} 9$ for APP substrate, or Notch $\varepsilon$-site specific antibody 9F3, specific for the amino-terminus of the NICD (beginning at V1755 of human Notch protein), as capture and anti-HA epitope tag antibody as the reporter for Notch substrate. Incubation of triplicate reactions in the presence of a range of inhibitor concentrations enabled determination of a dose-response for enzyme inhibition by the test compound and calculation of an $\mathrm{IC}_{50}$ value. Data analysis was performed using XLfit software package (IDBS Software Inc. Alalmeda, California, USA).

Recombinant APP or Notch fusion protein substrates (purified as described above) were incubated in reaction buffer (50 mM MES, pH 6.0, $400 \mu \mathrm{g} / \mathrm{mL}$ Type-V phospholipid, $5.6 \mathrm{mg} / \mathrm{mL}$ BigCHAP, $4 \mathrm{mM}$ DTT, 0.02\% TX100) at $20 \mu \mathrm{g} / \mathrm{mL}$ or $30 \mathrm{ug} / \mathrm{mL}$, respectively, with approximately $0.4 \mathrm{mg} / \mathrm{mL}$ enzyme preparation (1:100 to 1:250 dilution, depending upon batch to batch variation of specific activity) for $2 \mathrm{~h}$ at $37^{\circ} \mathrm{C}$ in the presence of protease inhibitors ( $1 \mathrm{mM} \mathrm{1,10-phenanthroline,} 5 \mathrm{ug} /$ $\mathrm{mL} \mathrm{E64,} \mathrm{and} 5 \mathrm{ug} / \mathrm{mL}$ leupeptin) in the presence of a concentration range of test inhibitor compounds. Reactions were quenched with $0.1 \%$ SDS for 10 minutes at room temperature, followed by addition of equal volume of specimen diluent $\left(1.5 \mathrm{mM} \mathrm{NaH}{ }_{2} \mathrm{PO}_{4} \cdot \mathrm{H}_{2} \mathrm{O}, 8 \mathrm{mM}\right.$ $\mathrm{Na}_{2} \mathrm{HPO}_{4} \cdot 7 \mathrm{H}_{2} \mathrm{O}, 8 \mathrm{mM} \mathrm{NaN}, 150 \mathrm{mM} \mathrm{NaCl}, 0.05 \%$ (volume/volume) Triton X-405 0.6\% (w/v) BSA, (globulin free).

\section{ELISA detection of $A \beta 40$ cleavage product}

The diluted enzyme reaction mixture was transferred to antibody 2G3-coated Immulon plates (specific for A $\beta 40$ carboxy-terminal neo-epitope) and incubated overnight along with A $\beta 1$ to 40 standards (32 to 2,000 $\mathrm{pg} / \mathrm{mL}$ in Specimen diluent). The ELISA was developed the following day by sequential one hour incubations with biotinylated $6 \mathrm{H} 9$ reporter antibody (Elan, A $\beta$ 17-28 specific, $0.25 \mu \mathrm{g} / \mathrm{mL}$ ) for one hour at room temperature, and Streptavidin-Alkaline Phosphatase Conjugate (Roche Molecular Biochemicals, Catalog No. 1089 161, Indianapolis, Indiana, USA), 1:1,000 in specimen diluent, one hour room temperature. The ELISA was developed using fluorescent alkaline phosphatase substrate, and the plate is read at $360 \mathrm{~nm}$ excitation/460 $\mathrm{nm}$ emission, gain approximately 50, in a CytoFluor 4000 (Applied Biosystems, Foster City, California, USA). The plates were washed $3 \mathrm{X}$ each with Tris-buffered saline/0.05\% Tween-20 between incubations with reporter antibody, detecting antibody, and fluorescent substrate.

\section{ELISA detection of NICD product}

Quenched in vitro gamma/Notch reactions were diluted 1:1 with casein diluent buffer containing $500 \mathrm{mM} \mathrm{NaCl}$, $0.02 \%$ TritonX-100 and plated onto Notch $\varepsilon$-cleavage site specific neoepitope mAb 9F3 (specific for the amino-terminus of NICD, beginning at V1755 of human Notch) coated immulon plates, for capture of the NICD reaction product overnight at $4^{\circ} \mathrm{C}$. NICD standards, prepared as described above, were serially diluted $2 \mathrm{X}$ over a concentration range from a starting concentration of $50 \mathrm{ng} / \mathrm{mL}$ for establishing a standard curve. The NICD reaction product and standards captured on the plate are detected with biotinylated-HA antibody $(1 \mu \mathrm{g} / \mathrm{mL}$ final, Roche Cat\# 1666851), followed by alkaline phosphatase conjugated streptavidin (diluted 1,000X from stock, Roche Cat\# 1089161). The plate was washed between each incubation step with Tris-buffered saline containing $0.1 \%$ Tween-20. The alkaline phosphatase reaction product is detected by incubation with $100 \mu \mathrm{l} /$ well Fluorescent Substrate A for 15 minutes at room temperature, and detected using Cytofluor plate reader at $360 \mathrm{~nm}$ excitation, $460 \mathrm{~nm}$ emission.

\section{Dual assay for simultaneous inhibition of $A \beta$ and Notch signaling in cells}

In order to test the potency and selectivity of gammasecretase inhibitors against two substrates (APP and Notch) simultaneously, we developed a dual-assay $\mathrm{CHO}$ cell line stably expressing APPSw, a Notch substrate lacking the ecto-domain, and a Notch responsive Luciferase reporter gene. As a first step, $\mathrm{CHO}$ cells stably over-expressing the APPsw were established. These cells secrete high levels of $A \beta$ peptide into the conditioned media from endogenous $\beta$ - and $\gamma$-secretase enzyme activity. A Notch intracellular domain responsive reporter gene, and the constitutive gamma-secretase Notch substrate, Notch $\Delta \mathrm{E}$, were stably introduced into $\mathrm{CHOsw}$ 
cells in a two-step process. CHOsw cells were first stably transfected to express a NICD responsive luciferase reporter gene construct (pGL2-CBF-Luc) [63]. Numerous stable clones ( $\mathrm{SCH}$ clones), were identified which displayed GSI sensitive Notch signaling upon transient expression with ZEDN, a rat Notch $\Delta \mathrm{E}$ expression construct [64]. Three clones exhibiting highest signal to noise NICD responsive luciferase activity ( $\mathrm{SCH}-32$, $\mathrm{SCH}-33$ and $\mathrm{SCH}-54$ ) were selected as the hosts for subsequent stable expression of Notch $\Delta \mathrm{E}$ by transfection with pIRES-ZEDN1in the final step of generating a dualassay cell line. Stable cell lines expressing rat Notch $\Delta \mathrm{E}$ were identified following transfection of the rat Notch $\Delta \mathrm{E}$ construct by selection with media supplemented with the $\gamma$-secretase inhibitor ELN-46719 (to suppress Notch/NICD toxicity), G418 (0.5 $\mathrm{mg} / \mathrm{mL})$, hygromycin $(1 \mathrm{mg} / \mathrm{mL})$ and puromycin $(2.5 \mu \mathrm{g} / \mathrm{mL})$. Antibiotic-resistant colonies (named SNC clones for the dual-assay components: APP $\underline{s}$ / Notch $\Delta E / \underline{C B F}$ ) were isolated and expanded for characterization of $\mathrm{A} \beta$ secretion and NICD responsive reporter gene activity (that is, luciferase signal in the presence versus absence of ELN46719). Based on optimal A $\beta$ secretion, and highest signal/background of reporter gene activity, a clone designated as SNC-204B8 was selected as the dual-assay stable line for subsequent profiling of APP selective $\gamma$-secretase inhibitors. Activity and selectivity of compounds for inhibition of $A \beta$ production versus Notch signaling was determined by plating the cells in 96-well plates in media lacking ELN46719 overnight. The following day, media was replaced and supplemented one hour later with an equal volume of additional media containing test compounds over a concentration range 0 $\mathrm{nM}$ to $40,000 \mathrm{nM}$ (final, in $10 \mathrm{X}$ dilution increments). The cells were treated with compounds overnight at $37^{\circ} \mathrm{C}$. The following day (Day 3), conditioned media was aspirated from cells for determination of $A \beta_{1-x}$ levels by ELISA [65], and cells were lysed for determination of Notch signaling by luciferase reporter gene activity (Promega, Madison, Wisconsin, USA) per manufacturers protocol.

\section{Analysis of APP metabolites from inhibitor treated cells} APP metabolites were analyzed by Western blot of SDSPAGE fractionated cell extracts and media derived from HEK293 cells stably expressing APPsw mutation following overnight treatment with different gamma-secretase inhibitors. Equal concentrations of protein (BioRad, Hercules, California, USA) from cell extracts were loaded for Western blot analysis. As reference GSI's we used LY411575, and the Merck active site directed isostere L-685458 for comparison with ELN-318463. Compounds were tested at two doses, approximately $1 \mathrm{X} \mathrm{ED}_{50}$ and approximately $10 \mathrm{X} \mathrm{ED}_{50}$ values in the $\mathrm{SNC}$ assay.
Different anti-APP antibodies were used to test the compounds for effects on $A \beta$, total secreted APP, $\beta$-sAPP, full length-APP and APP CTFs (C-terminal fragments of APP resulting from $\alpha$ - and $\beta$-secretase cleavage) as noted below. Secreted A $\beta$ in the conditioned media was quantified by ELISA using 2G3/3D6, which detects $A \beta$ (1 to 40). The full length APP and CTF Western blots were probed with anti-APP-c-terminal specific antibody (Sigma). Western blots of the conditioned medium samples (normalized for differences in cell density by protein concentration of the cell extracts) were probed with antibody 8 E5 [66] which recognizes total secreted APP, and 192sw $[67,68]$ which recognizes the carboxy-terminus of secreted APP arising from BACE cleavage of the APPsw overexpressed in these HEK293 cells.

\section{Binding site studies}

A displacement assay employing affinity capture of gamma-secretase complex with a biotinylated analog of active site isostere L685,458 [69] was developed to characterize binding site of the APP selective sulfonamides. PS1 and Nicastrin (Nct) Western blots were employed as readout for association of the gamma-secretase complex with the biotinylated probe. Displacement of the active site isostere by test compounds resulted in lowered intensity of PS1 and Nct bands on the immunoblots. The biotinylated active-site isostere inhibited APP cleavage in our gammaAPP assay with an IC50 = 11 nM. The results with L685,458 and LY-411575 were repeated three times, while the result observed with ELN318463 was replicated with a close structural analog of ELN318463 (not shown). The result shown with ELN475516 is from one of two independent replicates. Briefly, in the displacement assay a WGA affinity purified solubilized membrane preparation containing enriched gamma-secretase enzyme (from CHO S1 cells [70] prepared as described above), is diluted in incubation buffer under gammaAPP reaction conditions, and pre-cleared (30 minutes at room temperature) with streptavidin-sepharose resin (Amersham/GE Healthcare, Piscataway, New Jersey, USA) in order to remove endogenous biotinylated proteins and reduce nonspecific background signal. Biotinylated analog at $50 \mathrm{nM}$ is added to pre-cleared extract with or without competing test compounds at different concentrations, and incubated at $37^{\circ} \mathrm{C}$ for two hours. Streptavidin-sepharose is then added, and the mixtures are incubated at RT for 30 minutes. Following capture, the beads are centrifuged briefly (two minutes at 10,000 g) and washed twice with the incubation buffer, followed by Western blot analysis (Immobilon membranes, Millipore, Billerica, Massachusetts, USA) for PS1 NTF (antibody 1563, Chemicon, Millipore Bioscience Research Reagents, Temecula, California, USA) and Nicastrin (antibody N1660, Sigma, 
St Louis, Missouri, USA) specifically associated with the streptavidin resin through the biotinylated compound. The samples are run on 26 -well $10 \%$ to $20 \%$ acrylamide Tris- $\mathrm{HCl}$ gels (Criterion, BioRad), alongside serially diluted affinity captured enzyme samples from the same experiment (minus competing test compound) to provide a standard curve of on each gel for quantitation purposes. The PS1 and Nicastrin signals were detected by horse-radish peroxidase labeled secondary antibody followed by ECL chemiluminesence (Amersham) and the images were quantified by densitometry. The relative amount of PS or Nicastin remaining associated with affinity ligand in the unknown samples is calculated from the standard curve, and displacement of the biotinylated compound is reported as percentage of the protein signal in DMSO vehicle control samples. Binding assays in the presence of substrate were performed exactly as described above with the inclusion of $20 \mu \mathrm{g} / \mathrm{ml}$ (approximately $1 \mathrm{Km}$ ) of MBP-APPc125 recombinant fusion protein [61]. Preliminary experiments (not shown) indicated that under these conditions, we are able to capture $>90 \%$ of enzyme complex in the mix, and that $>90 \%$ of captured complex is competed by coincubation of the binding mix with $10 \mu \mathrm{M}$ L-685,458.

\section{Acute reduction of brain A $\beta$ in FVB and PDAPP mice}

All experiments were approved by the Institutional Animal Care and Use Committee (IACUC) of Elan Pharmaceuticals and conducted in accordance with its guidelines. Female, two- to three-month old, FVB/N mice were purchased from Taconic (Oxnard California, USA). Mice were housed four to five to a cage on a 12-hour light/dark schedule. Water and food were available ad libitum. FVB mice were treated orally with a single dose $(n=7 /$ dose $)$ of compound as indicated in the associated Figures. The test articles were formulated at various concentrations in a $10 \%$ Solutol $^{\circledR} /$ water vehicle (BASF Corp, Florham Park, New Jersey, USA) and dosed at $5 \mathrm{~mL} / \mathrm{kg}$ via oral gavage. Control animals were dosed with vehicle. Animals were sacrificed at three hours post dose, unless indicated otherwise. Cortical brain samples were collected, frozen on dry ice and stored at $-80^{\circ} \mathrm{C}$ until homogenization for determination of $\mathrm{A} \beta$ and compound levels. Thymus was collected, frozen in liquid nitrogen, stored at $-80^{\circ} \mathrm{C}$ for analysis of Hes1 levels. Blood samples were collected by cardiac puncture, processed to plasma, frozen on dry ice and stored at $-80^{\circ} \mathrm{C}$ until determination of compound levels by LC-MS-MS. Statistical analysis of data was performed using one-way ANOVA followed by Dunnett's.

\section{Repeat dose mouse seven-day toxicity study}

FVB mice, female, two to three months old, were treated orally with ELN475516 (15, 30, 100, 300, 600, and 1000 $\mathrm{mg} / \mathrm{kg} /$ dose) or LY411575 (5 mg/ kg/dose) twice per day (b.i.d.) for seven days ( $N=5$ per treatment group). The test articles were formulated at various concentrations in a $10 \%$ Solutol $^{\circledR} /$ water vehicle and dosed at $5 \mathrm{~mL} / \mathrm{kg}$ via oral gavage. Control animals were dosed with vehicle. All animals were sacrificed at three hours post last dose. Cortical brain samples were collected, frozen on dry ice and stored at $-80^{\circ} \mathrm{C}$ until homogenization for determination of $A \beta$ and compound levels. Blood was collected, (via cardiac puncture), processed for $\mathrm{CBC}$, or processed to plasma and frozen on dry ice and stored at $-80^{\circ} \mathrm{C}$ until determination of compound levels. Duodenum and ileum, as well as other tissues, were collected from each treatment group and fixed in 10\% formalin for histopathology evaluation. Body weight was reported as percent change from the base line and compared to vehicle control group in the one-way ANOVA Dunnett's test for statistical analysis. Relative organ weight was calculated by the absolute organ weight/body weight. Statistical analysis was done by Prism software/one-way ANOVA (and nonparametric) Dunnett's test for all toxicity endpoints. Most endpoints examined were significant at $P<0.001$ except on one parameter which was $P<0.01$ and is noted in the appropriate figure legend. Duodenum and ileum tissues were sectioned and double stained with H\&E (hematoxylin and eosin) plus PAS (periodic acidSchiff stain) for histopathologic evaluation.

\section{Endogenous mouse brain $A \beta$ ELISA}

Cortical brain samples were homogenized in $5 \mathrm{M}$ guanidine and $A \beta_{x-40}$ was estimated in a sandwich ELISA utilizing the monoclonal antibodies 266 (made against 16 to 28 amino acid sequence of $A \beta$ ) as the capture, and $2 \mathrm{G} 3$ (terminal specific to $\mathrm{A} \beta 40$ ) as the reporter. This assay estimates the concentration of $\mathrm{A} \beta$ peptides ending at amino acid 40, without specificity for amino termini upstream of residue 16 . Statistical significance was determined by ANOVA.

\section{Quantitation of Notch signaling RNA endpoints Hes1/ Math1}

Tissues were homogenized in lysis buffer and processed for total RNA extraction using the QIAGEN Rneasy 96-well plate technology with post-column Dnase treatment. The concentration of RNA per sample was measured by a RiboGreen RNA quantitation assay (Invitrogen). Math1 (Atonal homolog) or Hes1 mRNA levels were quantified by a TaqMan RT-PCR assay and results were normalized by RNA sample concentration. The sequences of the primers and probes employed in the Taqman assay were as follows: Hes1 forward primer: CGGCTTCAGCGAGTGCAT; Hes1 reverse primer: CGGTGTTAACGCCCTCACA; Hes1 probe: AACGAGGTGACCCGCTTCCTGTCC. Math1 Forward 
primer: AGCTGGACGCTTTGCACTTT; Math1 reverse primer: TCTGTGCCATCATCGCTGTT; Math1 Probe: 5'FAM-CAGCTTTCGAGGACCGGGCCC-TAMRA3'. All Taqman reagents were acquired from Applied Biosystems, Inc., Foster City, CA, USA.

\section{Results}

To enable discovery of novel APP selective gammasecretase inhibitors, we developed biochemical assays for substrate cleavage followed by ELISA employing neoepitope specific monoclonal antibodies for detection of products. A detergent solubilized, lectin affinity column enriched, enzyme preparation derived from IMR-32 neuroblastoma cells was incubated with either recombinant APP-C125, or a Notch fusion protein substrate. These substrates replicate natural processing of a site equivalent to the carboxy-terminus of $A \beta 40$, or the $\mathrm{S} 3 /$ $\varepsilon$-site of Notch, respectively, with Michaelis-Menten kinetics (APP substrate $K_{m}=358 \mathrm{nM}$, Notch substrate $\mathrm{K}_{\mathrm{m}}=1.52 \mu \mathrm{M}$, Figure S1 in Additional file 1). The products of this reaction were detected and quantified by a sandwich ELISA employing neo-epitope specific capture monoclonal antibodies 2G3 (Aß40 specific), or 9F3 (specific for NICD N-terminus, the C-terminal cleavage product derived from Notch $\Delta \mathrm{E}$ in cells [71-73], Figure S2 in Additional file 2), and appropriate detection antibodies as illustrated in Figure 1a. Henceforth, we refer to this assay measuring gamma-secretase cleavage of APP fusion protein substrate at $\mathrm{A} \beta 40$ site as the gamma:APP assay, and cleavage of Notch $\Delta \mathrm{E} \Delta \mathrm{C}$ substrate at Notch $\mathrm{S} 3 / \varepsilon$-site as gamma:Notch assay.

A high-throughput screen of a chemical library employing the gamma:APP assay was conducted to discover novel inhibitors of gamma-secretase. Hits from the primary screen (defined as $>25 \%$ inhibition at $10 \mu \mathrm{M}$ ) were characterized in secondary assays for dose response, non-specific inhibition (for example, of non-gamma:APP enzymatic reactions, assay detection reagents), and selectivity for inhibition of APP cleavage versus Notch cleavage by gamma-secretase. A number of hits comprising a novel series of $\mathrm{p}$-chlorobenzene-caprolactam sulfonamide compounds demonstrated concentration dependent and APP > Notch selective inhibition of gamma-secretase, as exemplified by ELN158162, which displayed an $\mathrm{IC}_{50}$ in gammaAPP assay of $0.65 \mu \mathrm{M}$, compared with an $\mathrm{IC}_{50}$ of approximately $25 \mu \mathrm{M}$ in the gamma:Notch assay, resulting in a selectivity ratio of approximately 40 (Figure $1 \mathrm{~b}$ ).

To test for APP-selective inhibition of gammasecretase by the screening hits in a cellular context, we developed a stable $\mathrm{CHO}$ cell line co-expressing APPSw, rat Notch $\triangle \mathrm{E}$ [64], and an NICD responsive CBF-Luciferase reporter gene [63] (SNC cells), to assay endogenous gamma-secretase enzyme. Inhibition of secreted $A \beta$ was quantified by an ELISA specific for $A \beta_{1-x}$ using conditioned media harvested from cells, and Notch signaling was detected using a luciferase reporter assay in cellular lysates from cells treated overnight with a concentration range of inhibitor compounds. The profile of reference non-selective gamma-secretase inhibitors compared with the HTS hit and selective lead compounds in the SNC dual cell assay corroborated the biochemical enzymatic assay data, demonstrating APP selective inhibition of cellular gamma-secretase by the screening hit and select lead compounds (Table 1).

Biochemical characterization of the inhibitors revealed they behave as classical GSIs in that they elevate C99 with no effects on SAPP $\alpha$ or sAPP $\beta$ (Figure 2), and are equipotent inhibitors of $A \beta 40$ and $A \beta 42$ (Figure $S 3$ in Additional file 3). The compounds lowered secreted $A \beta$ in conditioned media at the concentrations tested for effects on APP metabolites (Figure 2d). Binding site studies employing biotin labeled active site isostere as affinity ligand for enriched gamma-secretase enzyme (derived from CHO-S1 cells [70], flow-chart of assay shown in Figure S4 in Additional file 4) confirmed competitive displacement of affinity ligand by its nonbiotinylated analog L-685,458 (Figure 3a), consistent with published results [69], as well as by very high concentrations of LY411575 (Figure 3b). Specifically, we observed a $50 \%$ displacement of a biotinylated active site isostere probe by L-685,458 at concentrations approximately three-fold above its $\mathrm{IC}_{50}$ in the gammaAPP assay, whereas LY-411575 displaced $50 \%$ of biotinylated active site isostere probe at concentrations $500 \mathrm{X}$ to $1,000 \mathrm{X}$ above its $\mathrm{IC}_{50}$ value in the gammaAPP assay. Sulfonamides did not displace biotinylated active site isostere in competitive binding assays in the absence of substrate (Figure 3c, d, left half). However, in the presence of $1 \mathrm{~K}_{\mathrm{m}}(20 \mu \mathrm{g} / \mathrm{ml})$ MBP-C125 substrate, ELN318463 and ELN475516 were able to displace the active site isostere (Figure 3c, d, right half) at an $\mathrm{ED}_{50}$ of $23 \mu \mathrm{M}$ and $0.14 \mu \mathrm{M}$, respectively (data not shown). These values represent an approximately 2,000X and $67 \mathrm{X}$ multiple over the $\mathrm{IC}_{50}$ values of the two compounds in the gammaAPP assay.

In vivo testing of a benzene caprolactam sulfonamide, ELN318463 [59], possessing favorable oral bioavailabilty ( $\mathrm{F}=30 \%$ in rat), revealed dose-dependent acute reduction of brain $A \beta_{1-x}$ species in PDAPP mice (Figure 4a). In contrast, acute reduction of $A \beta_{x-40}$ species in nontransgene FVB mice (Figure $4 \mathrm{~b}$ ) was equivalent at both doses tested. Reduction of $A \beta_{x-40}$ in PDAPP also was not dose responsive $(20 \%$ and $25 \%$ reduction at $30 \mathrm{mg} /$ $\mathrm{kg}$ and $100 \mathrm{mg} / \mathrm{kg}$, respectively, data not shown). The lack of a dose response in $A \beta_{x-40}$ species in PDAPP \& FVB mice compared with $A \beta_{1-x}$ species in PDAPP mice can not be explained by differences in terminal 


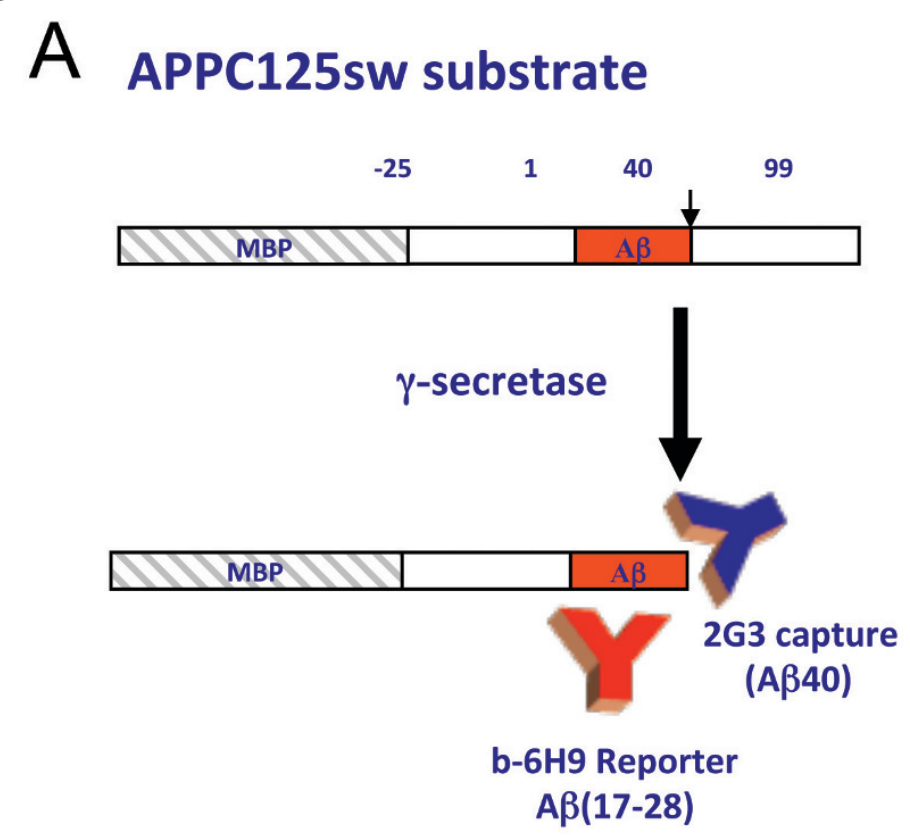

\section{mNotch-100 substrate}
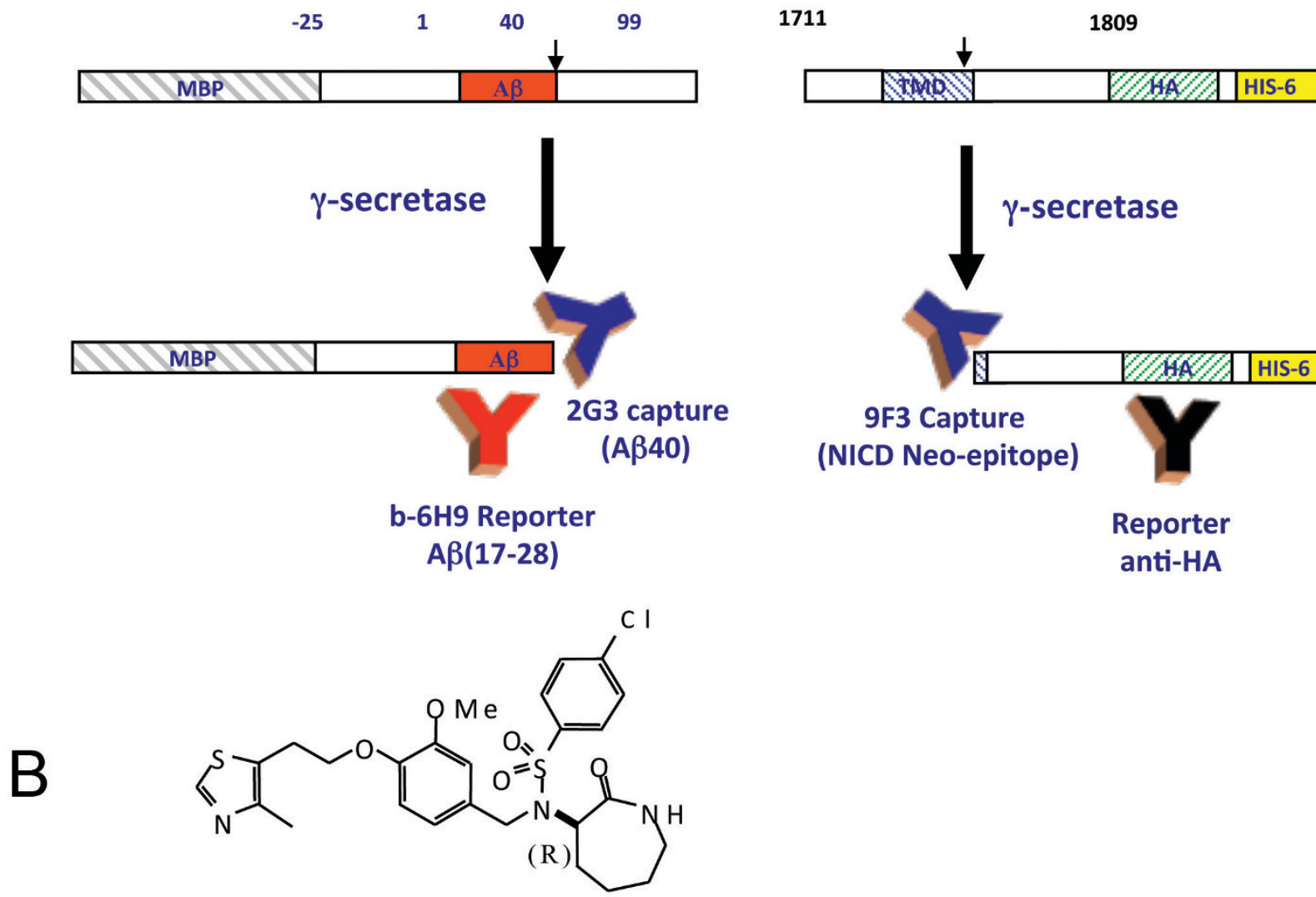

\section{ELN 158162}

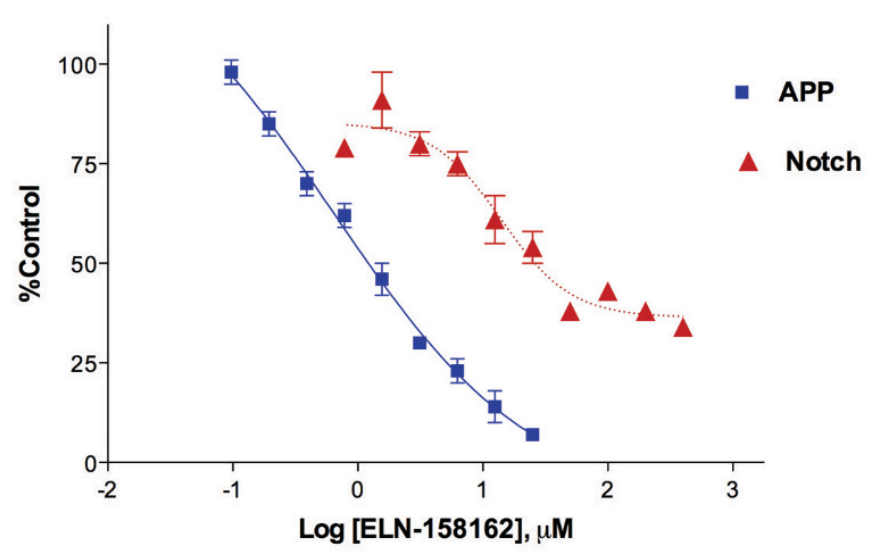

Figure 1 Schematic illustration of in-vitro assays, and dose response curves of an APP selective gamma-secretase inhibitor (a) Recombinant E.coli expressed fusion protein substrates APP MBP-C125Sw (left side, numbering relative to A $\beta$ peptide residues, red box) or mNotch100 substrate (right hand side, numbering relative to initiator methionine residue) were incubated in separate reactions with partially purified solubilized gamma-secretase enzyme from IMR-32 cells as detailed in methods. The reactions products were analyzed by ELISA using 2G3/6H9 ELISA for $A \beta_{X-40}$ for GammaAPP assay product, or the 9F3/anti-HA ELISA for NICD, the GammaNotch assay product. MBP, N-terminal fusion with maltose binding protein (grey hatched box); TMD, transmembrane domain (blue hatched box); HA, hemagglutnin antigen epitope tag (green hatched box); HIS-6, hexahistidine residue epitope tag (yellow box). (b) Dose response curve demonstrating APP-selective inhibition from a representative screening hit ELN158762. The $I_{50}$ values for inhibition of APP and Notch substrate cleavage, and selectivity ratio in the biochemical assays with this compound are reported in Table 1. 
Table 1 In-vitro Properties of Gamma-Secretase Inhibitors

\begin{tabular}{|c|c|c|c|c|c|c|}
\hline Compound & $\begin{array}{l}\text { gamma:APP } \\
\text { IC50 (nM) }\end{array}$ & $\begin{array}{r}\text { gamma:Notch } \\
\text { IC50 (nM) }\end{array}$ & $\begin{array}{r}\text { enzyme selectivity } \\
\text { (APP/Notch) }\end{array}$ & $\begin{array}{r}\text { SNC A } \beta \text { EC50 } \\
(\mathrm{nM})\end{array}$ & $\begin{array}{r}\text { SNC Notch Signaling } \\
\text { EC50 (nM) }\end{array}$ & $\begin{array}{r}\text { Cellular Selectivity } \\
\text { (APP/Notch) }\end{array}$ \\
\hline L-685,458 & $0.63(1)$ & nd & NA & $13.2 \pm 4.5$ & $184 \pm 145$ & 14 \\
\hline LY411575 & $0.035(1)$ & $0.082 \pm 0.008$ & 2.4 & $\begin{array}{r}0.116 \pm 0.011 \\
(3)\end{array}$ & $1.8 \pm 1.35$ & 16 \\
\hline ELN158162 & 650 & 14,000 & 21.5 & nd & nd & NA \\
\hline ELN318463 & $37.2 \pm 18(51)$ & $1,889 \pm 722$ & 51 & $23.4 \pm 8.6(10)$ & $2,818 \pm 670(10)$ & 120 \\
\hline ELN475516 & $2.06 \pm 0.35(16)$ & $29.81 \pm 2.59$ & 14.5 & $\begin{array}{r}8.73 \pm 3.96 \\
(298)\end{array}$ & $719 \pm 224.6$ (298) & 82 \\
\hline
\end{tabular}

Potency For Inhibition Of App And Notch Processing by select gamma-secretase inhibitors in enzyme, as well as cellular assays described in text. The value in parentheses next to each IC50 indicates the number of independent test occasions used to derive the IC50 value. Note: Cellular selectivity of L-685,458 was determined prior to development of the SNC assay using different cellular assays for $A \beta$ production and Notch signaling.

Abbreviations: APP, amyloid precursor protein; SNC, a stable CHO cell line co-expressing APPSw, rat Notch $\triangle \mathrm{E}$, and an NICD responsive CBF-Luciferase reporter gene used to simultaneously assay inhibition of $A \beta$ production, and Notch signaling; $A \beta$, amyloid beta-peptide.

compound levels in the target organ at the two doses tested, nor by assay differences. Brain levels of ELN318463 at $30 \mathrm{mg} / \mathrm{kg}$ were $0.754 \mu \mathrm{M}$ in FVB brains and $0.69 \mu \mathrm{M}$ in PDAPP brains, and at $100 \mathrm{mg} / \mathrm{kg}$ dose the levels were $2.7 \mu \mathrm{M}$ in FVB brains and $1.87 \mu \mathrm{M}$ in PDAPP brains. Discordance between $A \beta_{1-40}$ and $A \beta_{x-40}$ in BACE $\mathrm{KO}$ or wild-type BACE inhibitor treated mice has been reported [74]. However, our observations cannot be explained by differences in assays employed for measuring $A \beta_{1-x}$ vs. $A \beta_{x-40}$, as observed by Nishitomi et al. [74], because both assays used in this study are insensitive to the A $\beta$ P3 fragment (product of alphaand gamma-secretase cleavages) by virtue of the capture antibody employed (see Materials and methods).

Lead optimization toward discovery of more potent analogs revealed critical requirement for proton donor in caprolactam ring of benzene-sulfonamides, corroborated by pyrazole substituted piperidines as scaffold replacements [60] (Figure S5 in Additional file 5). The prototype pyrazolylazabicyclo(3.3.1)nonane ELN475516 supported this hypothesis by demonstrating improved in vitro potency, while retaining APP selectivity of the caprolactam sulfonamide parent lead series (Table 1). Furthermore, the novel fused bi-cyclic gamma-secretase inhibitor demonstrated dose dependent in vivo activity for acute reduction of cortical $A \beta_{1-x}$ in the PDAPP transgene mouse model $(31 \%$ and $45 \%$ reduction of $\mathrm{A} \beta_{1-\mathrm{x}}$ at three hours following a single oral dose of 10 $\mathrm{mg} / \mathrm{kg}$, and $30 \mathrm{mg} / \mathrm{kg}$, respectively, data not shown) as well as cortical $A \beta_{x-40}$ in wild type FVB mice (Figures $5 \mathrm{a}, 6 \mathrm{a}$, and $7 \mathrm{a})$.

In acute single dose studies, ELN475516 lowered brain $A \beta$ at three hours post treatment in a dose dependent manner, effecting a $40 \%$ reduction at the lowest dose tested $(30 \mathrm{mg} / \mathrm{kg})$, and up to a $71 \%$ reduction at $300 \mathrm{mg} / \mathrm{kg}$ (Figure 5a). A statistically significant reduction of thymic Hes-1 mRNA (an acute end-point of Notch signaling inhibition) was detected at the highest dose tested (300 mg/kg. Figure $5 \mathrm{~b})$. Terminal plasma compound levels at the highest dose tested were 12.3 $\mu \mathrm{M}$, or a more than six-fold multiple over the cellular $\mathrm{IC}_{50}$ for inhibition of Notch signaling. By comparison, acute treatment with $10 \mathrm{mg} / \mathrm{kg}$ of the non-selective GSI LY411575 concomitantly lowered brain $\mathrm{A} \beta$ (74\%) and thymic Hes-1 mRNA (60\%) (Figure 5a, b, respectively). The acute treatment study shown in Figure 5 provides a benchmark for reduction of brain $A \beta$ in FVB mice treated with $30 \mathrm{mg} / \mathrm{kg}$ ELN475516 at three hours post dose.

To characterize the duration of efficacy in relation to compound exposure at different doses for ELN475516, we conducted a time course study in mice treated with 30,100 , and $300 \mathrm{mg} / \mathrm{kg}$, and terminated at varying time points following single dose. The results, shown in Figure 6, indicate that Cmax was achieved at one hour post dose (Figure $6 \mathrm{~b}$ ), maximal reduction of brain $A \beta$ was observed at three hours post dose (Figure 6a), and significant reduction was maintained at 10 hours post dose at all doses tested $(28 \%, 33 \%$, and $56 \%$, at 30,100 , and $300 \mathrm{mg} / \mathrm{kg}$, respectively). At 14 hours post dose, a significant $14 \%$ and $29 \%$ reduction was observed in mice treated with 100 and $300 \mathrm{mg} / \mathrm{kg}$, with $A \beta$ levels returning to baseline by 24 hours post dose in all treatment groups. The results shown in Figure 6a suggest that brain $A \beta$ was lowered by $>25 \%$ for 24 hours per day in mice dosed $\geq 300 \mathrm{mg} / \mathrm{kg}$. Dose dependent increases in brain and plasma exposure were seen in mice at the three doses tested in this single dose study, where total exposure in the $300 \mathrm{mg} / \mathrm{kg}$ group was $24 \mathrm{X}$ the $30 \mathrm{mg} /$ $\mathrm{kg}$ group, and $3 \mathrm{X}$ the $100 \mathrm{mg} / \mathrm{kg}$ group (Figure $6 \mathrm{c}$ ).

To provide a critical test of improved in vitro selectivity in an in vivo context, we developed a seven-day mouse safety model utilizing a b.i.d dosing regimen in wild-type FVB mice. Mice treated with a non-selective GSI (LY411575) at $5 \mathrm{mg} / \mathrm{kg}$ b.i.d. demonstrated $83 \%$ reduction of brain $A \beta$ (Figure 7a). However, the reduction of brain $A \beta$ at this dose was accompanied by concomitant effects on endpoints related to Notch signaling in peripheral organs. These effects included a decrease 


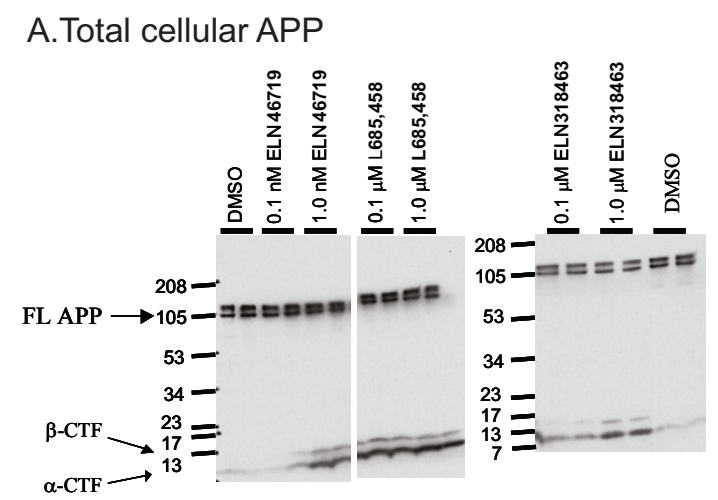

B. Secreted APP $\alpha$

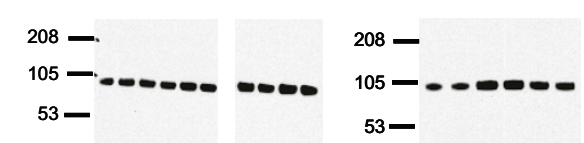

C. Secreted APP $\beta$

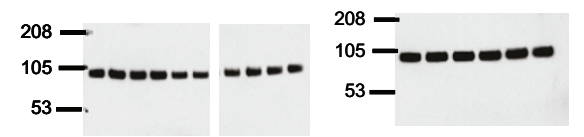

D. A $\beta 1-40$ in conditioned media

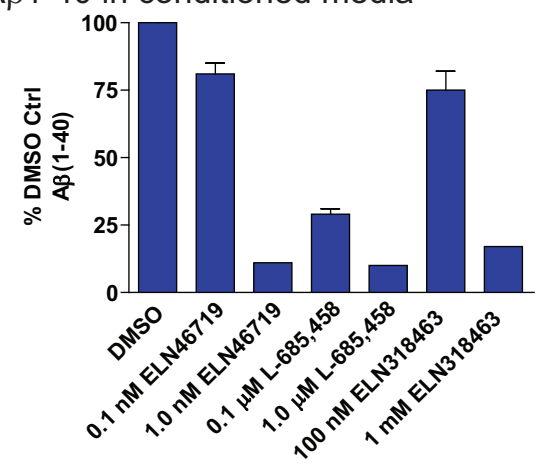

Figure 2 Novel sulfonamides exhibit properties in common with classic gamma-secretase inhibitors. Western blots of cell extracts (a) and media (b, c) after treatment of cultures in duplicate of with gamma-secretase inhibitors indicated above the lanes. Compounds were tested at two doses, approximately $1 \mathrm{XED}_{50}$ and approximately $10 \times E_{50}$ based on cellular assay results. (a) Full length and c-terminal fragments of APP total cellular lysates recognized by an antibody against the C-terminus of APP (Sigma A8717). The reference gamma-secretase inhibitors $L-685,458$ and ELN46719 (analog of LY411575, see methods), as well as the novel sulfonamides tested stabilize both $\alpha$-CTF and $\beta$-CTF in a dosedependent manner, and none of the compounds significantly affect steady-state levels of full-length APP. (b, c) Western blots of the conditioned media samples from this same experiment probed with antibody 8E5 against total secreted APP (b), and 192Sw against the $\beta$-secreted APP formed by BACE cleavage of the Swedish mutant APP over-expressed in these HEK293 cells (c). No significant effect on either total SAPP $\alpha$ or SAPP $\beta$ was seen by any of the gammasecretase inhibitors. (d) Quantification of $A \beta_{1-40}$ in the conditioned media. The results suggest that the sulfonamide only affects gamma-secretase cleavage of APP, and does not appear to have nonspecific effects on overall APP metabolism or cell viability in HEK293 cells. in body and thymus weight, increase in circulating neutrophils, goblet cell hyperplasia, plus elevated Math1 mRNA endpoints in duodenum and ileum indicative of Notch signaling inhibition, as shown in Figure 7c, d, Figure 8 and Figure 9c, d. Hence, the mouse seven-day b.i.d. treatment model accurately reflects systemic as well as target organ toxicities described for this non-selective GSI, consistent with reports in other models $[28,29,75]$.

Based on the observed acute safety and pharmacokinetics (Figures 5 and 6), FVB mice were treated twice daily with a range of oral doses of ELN475516 for seven days as described in methods. The pharmacological and safety end-points following this seven-day treatment are shown in Figures 7, 8 and 9. Treatment of mice with ELN475516 at the lowest dose tested $(15 \mathrm{mg} / \mathrm{kg} /$ dose, b.i.d.) resulted in a statistically significant $33 \%$ reduction of brain $A \beta$ (at three hours post last dose), in close agreement with the acute treatment study. The pharmacological effect of ELN475516 on brain A $\beta$ levels in FVB mice was dose dependent, with maximal effect $(74 \%$ reduction) observed at $\geq 100 \mathrm{mg} / \mathrm{kg}$, and exhibited a clear pharmacokinetic/pharmacodynamic relationship in which brain compound levels correlated inversely with brain $A \beta$ levels (Figure $7 b$ ). In contrast with a statistically significant effect of the non-selective GSI LY411575 on molecular Notch signaling endpoints (Math-1 mRNA levels in duodenum and ileum, Figure 7c, d), systemic Notch target organ related endpoints (thymus and small intestine weights relative to body weight, Figure $8 \mathrm{c}, \mathrm{d}$ ), as well as systemic endpoints of general toxicity (body weight, circulating neutrophils, Figure 8a, b), ELN475516 had no significant effect relative to vehicle treated controls on these endpoints at all doses tested.

We assessed cell homeostasis in the intestinal tract as a more sensitive indicator of in vivo inhibition of Notch signaling by gamma-secretase inhibitors. Goblet cell hyperplasia was readily apparent in mice treated with $5 \mathrm{mg} / \mathrm{kg}$ of non-selective GSI LY411575 in both the duodenum and ileum of the intestinal tract (Table 2, Figure 9c and 9d), consistent with published observations $[28,29,41,75]$. Goblet cell hyperplasia was not observed at any dose of ELN475516 in the duodenum. In the ileum, although scattered minimal to mild goblet cell hyperplasia was observed in a subset of animals from some dose groups (Figure 9e-g), the changes in goblet cell numbers observed were not dose-related. The lack of effect on gastrointestinal tract cell homeostasis in mice treated with up to $1,000 \mathrm{mg} / \mathrm{kg} / \mathrm{dose}$ ELN475516 b.i.d. is consistent with lack of effect on molecular and systemic readouts of Notch signaling shown in Figures 7 and 8. Terminal plasma levels of compound in the lowest and highest treated dose were 


\section{A}

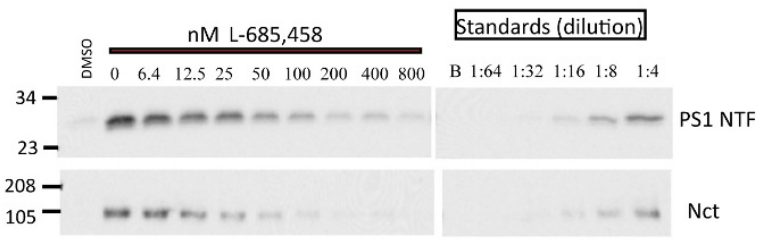

\section{B}

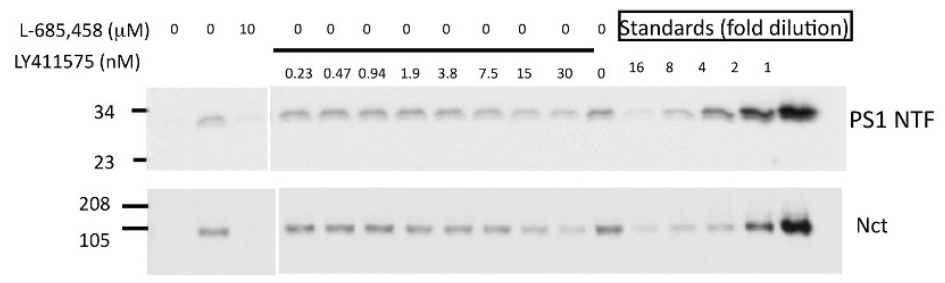

C

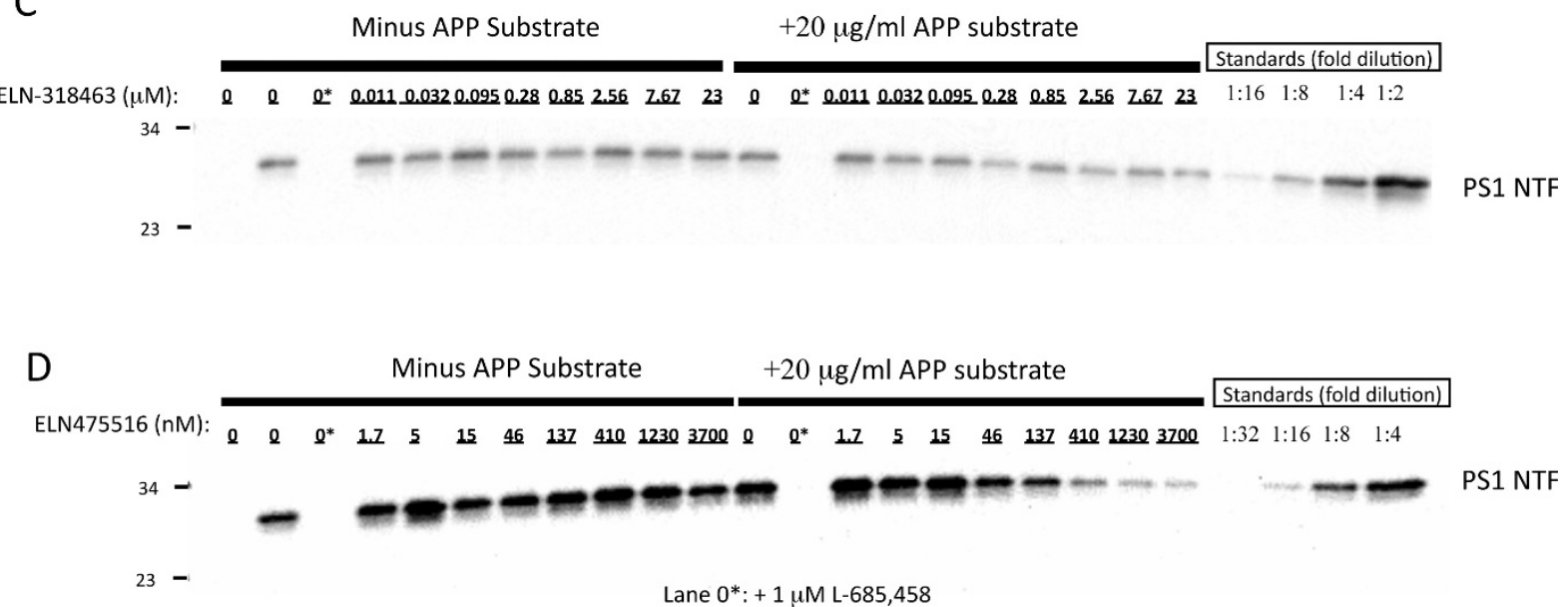

Figure 3 Binding site analysis by competitive displacement of biotinylated active site isostere. A competitive binding assay employing a biotin conjugated active site isostere to capture gamma secretase from a partially purified cell extract, plus or minus co-incubation with increasing concentrations of reference or test gamma secretase inhibitors, was developed to characterize inhibitor binding site. The eluted enzyme captured on neutravidin beads was detected on western blots with antibodies recognizing either PS-1 amino-terminal fragment (PS1$\mathrm{NTF}$ ), or Nicastrin (Nct). The binding assay was carried out using $50 \mathrm{nM}$ affinity probe together with different concentrations of competing compounds. Serial dilutions of affinity captured enzyme were included on the gels to provide a standard curve for densitometric quantitation of test samples following autoradiography of the western blots. (a) The biotinylated isostere is displaced by its non-biotinylated analog L-685,458 in a concentration dependent manner. In subsequent experiments, a 200-fold excess of L-685,458 was employed as a positive control. (b) LY411575 was tested for its ability to displace active site isostere at concentrations ranging up to 1000 -fold its $I C_{50}$ in the Gamma APP enzyme assay. There is no significant displacement of the active site directed compound by at concentrations below 200 -fold its $I C_{50}$ in the enzyme assay. At higher concentrations, a modest dose-dependent effect of LY411575 to displace the active-site-directed compound is observed on both Western blots. Previous observations revealed substrate concentration affects the potency of sulfonamides in cell and enzyme assays (unpublished). Hence, the ability of sulfonamides to displace the active site directed probe was tested in the absence (c and $\mathbf{d}$, left side) or presence (c and d, right side) of $1 \mathrm{Km}$ substrate (MBP-C125sw). Substrate was added to enzyme concurrently with test compound and affinity ligand. In the presence of added APP, the sulfonamides displace the active site probe in a dose-dependent manner. (c) No displacement of active site probe is observed by ELN318463 in the absence of substrate. In the presence of substrate, ELN318463 displaces approximately 50\% of the active site probe at a concentration of approximately 2,000-fold its $I_{50}$ in the Gamma APP assay. (d) ELN-475516 does not displace the active site probe at concentrations ranging up to 2,000X its $\mathrm{IC}_{50}$ in the gammaAPP assay. However, in the presence of substrate, ELN475516 displaces $50 \%$ of the active site probe at a concentration equivalent to approximately 67-fold its Gamma APP IC $C_{50}$. The results shown in (c) and (d) suggest displacement of active site isostere from gamma-secretase by benzene caprolactam and fused pyrazolo-bicyclic sulfonamide is influenced by the presence of substrate. 


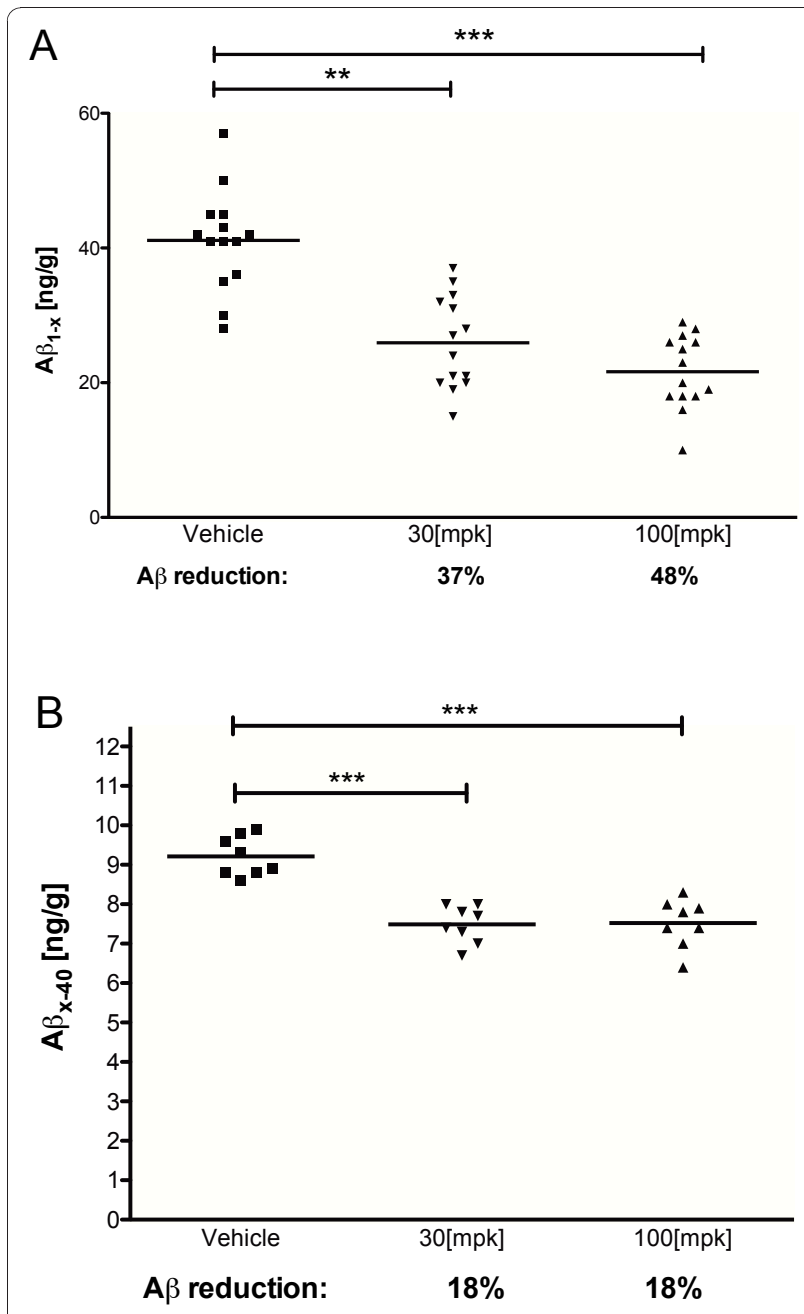

Figure 4 Acute reduction of brain A $\beta$ by ELN318463 in PDAPP (a) and FVB mice (b). The mice were dosed orally with vehicle, or ELN318463 at $30 \mathrm{mg} / \mathrm{kg}$ or $100 \mathrm{mg} / \mathrm{kg}$ and sacrificed $3 \mathrm{~h}$ post treatment. Brain $A \beta_{1-x}$ in PDAPP (a), or $A \beta_{x-40}$ in FVB (b) was quantified by ELISA following extraction in guanidine buffer as described in methods. ${ }^{* *}$ denotes $P<0.01$, ${ }^{* * *}$ denotes $P<0.001$ by Mann-Whitney in A, and two-tailed Students $t$-test in (b).

$0.187 \mu \mathrm{M}$, and $12.3 \mu \mathrm{M}$, respectively. An in vivo selectivity of $>65$ for ELN475516 based on either dose or terminal plasma levels of compound is estimated, where minimal efficacious dose is defined as $\geq 25 \%$ A $\beta$ reduction in the brain at study termination (that is, three hours post last dose), and the minimum toxic dose is defined as the dose producing a statistically significant elevation of Math1 mRNA levels. Hence, the in-vivo selectivity of ELN475516 corroborates the improved biochemical as well as cellular selectivity for inhibition of $A \beta$ production from APP by gamma-secretase, compared with inhibition of Notch processing and Notch signaling. Limiting Nglucuronidation precluded longer-term studies with ELN475516 in mice (or other models). However,

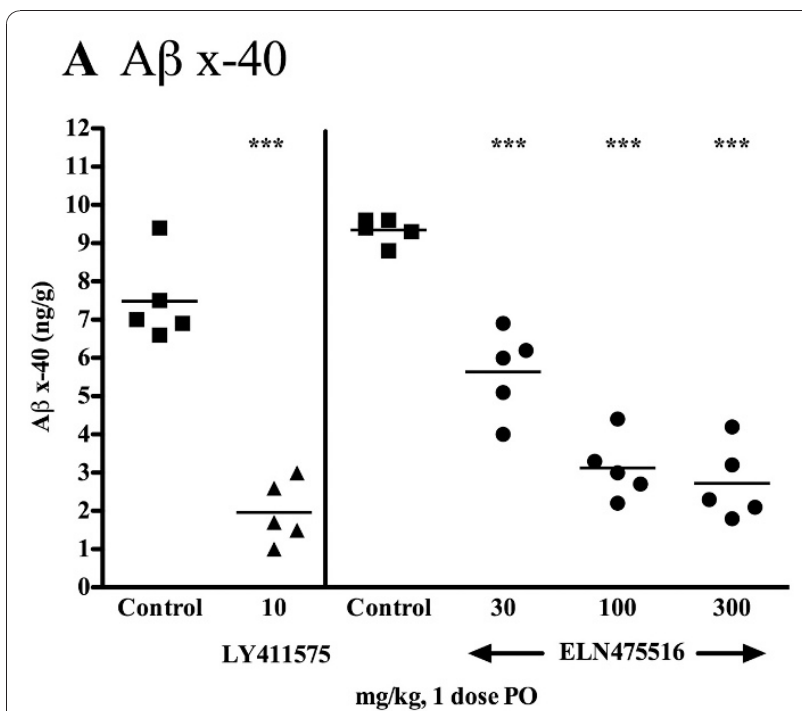

B Hes-1

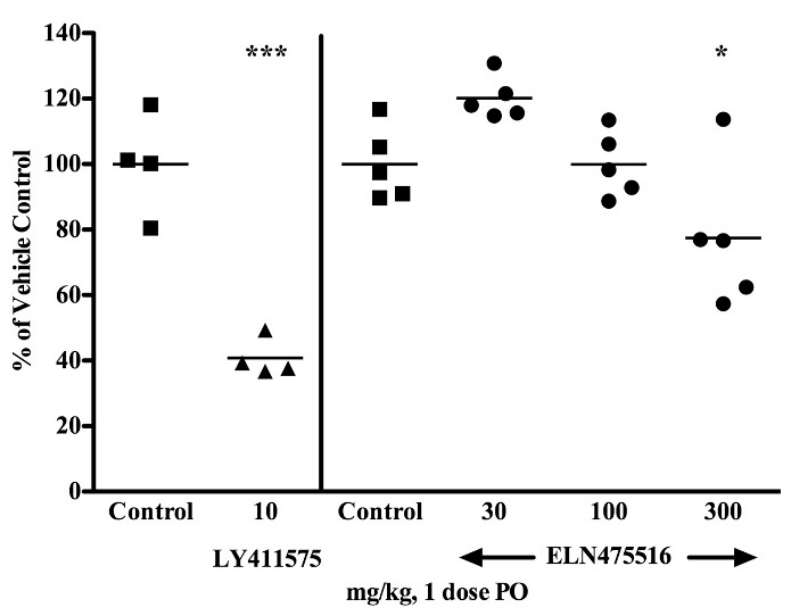

Figure 5 Reduction of brain $A \beta$ and thymic Hes-1 in wild-type FVB mice after treatment with gamma-secretase inhibitor. Female FVB mice were treated orally with a single dose of ELN475516 (30, 100 or 300 mg/kg), LY411575 (10 mg/kg) or vehicle and sacrificed at three hours post dose. (a) Cortical $A \beta_{x-40}$ levels, estimated by ELISA from guanidine extracted brain homogenates. (b) Thymic Hes-1 mRNA levels, estimated by TaqMan RT-PCR. Statistical significance between treatment groups and vehicle was determined by ANOVA and Dunnett's test. ${ }^{* *} P<0.001,{ }^{*} P<0.05$

ELND006, a lead optimized analog derived from ELN475516, was well tolerated for three and six months in a chronic PDAPP mouse study at doses which affected AD pathology in the absence of any toxicity [76].

\section{Discussion}

To discover novel APP-selective inhibitors of gammasecretase, we developed cell-free assays employing recombinant APP or Notch substrates incubated with 

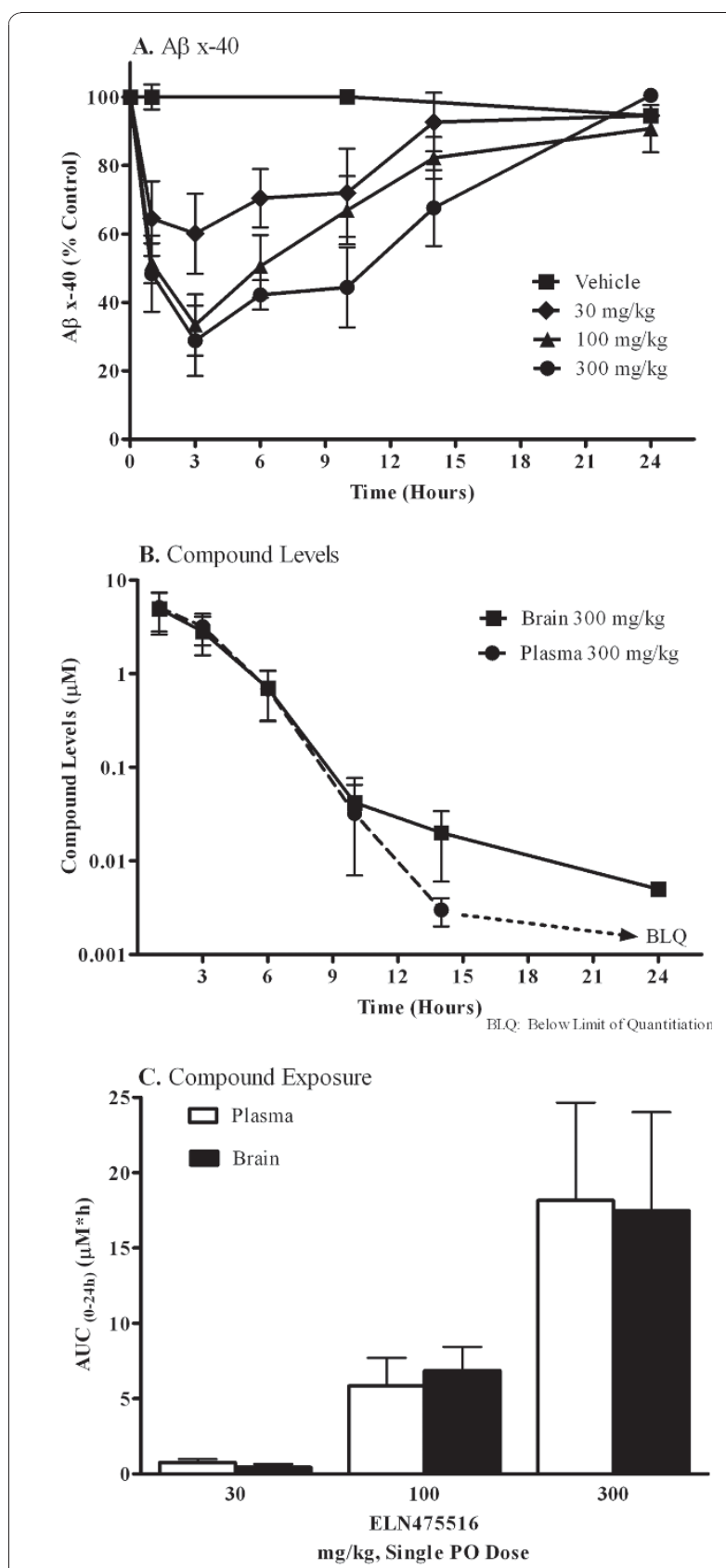

Figure 6 Time course of brain $A \beta$ reduction in wildtype FVB mice after treatment with a single dose of ELN475516. Female FVB mice were treated orally with a single dose of ELN475516 (30, 100 or $300 \mathrm{mg} / \mathrm{kg}, n=5 /$ dose group) or vehicle and sacrificed at 1 , $3,6,10,14$ and 24 hours post dose. (a) Cortical $A \beta_{x-40}$ levels, estimated by ELISA from guanidine extracted brain homogenates. (b) ELN475516 levels in plasma and brain estimated by LC/MS/MS. (c) ELN475516 plasma and brain exposure over 24 hours ( $A \cup C_{0-24}$ ).

an enriched enzyme preparation derived from IMR-32 neuroblastoma cells. We utilized this biochemical assay for APP cleavage by gamma-secretase in a high-throughput screen of a chemical library and discovered amino- caprolactam sulfonamide leads, which demonstrated APP-selective inhibition of gamma-secretase activity in vitro. The selectivity of our lead series was confirmed in a cellular assay. Comparison of APP selectivity of nonselective reference GSIs in cell-free compared with cellular (SNC) assay reveals a basal 15-22X right-ward shift for selectivity in the cellular assay compared with the cell-free assay with reference non-selective GSI's L-685,458 and LY411575. This observed shift in selectivity between a cell-free assay which measures inhibition of substrate cleavage, versus downstream signaling events, likely reflects a difference between inhibition of Notch cleavage vs. Notch signaling. Our observation is consistent with findings that Notch signaling was only reduced 35 to $48 \%$ in cells treated with concentrations of peptidomimetic GSIs which abolished NICD formation to below detectable levels [77].

The benzene caprolactam sulfonamide ELN381463 [59] lowered brain $A \beta_{1-x}$ in a concentration dependent manner in PDAPP mice; however, reduction of $A \beta_{x-40}$ was nominal and did not exhibit a concentration dependent effect in two mouse lines tested (PDAPP and FVB). This discordance in a concentration effect on reduction of brain $A \beta$ species cannot be explained by differences in drug levels in the two mouse lines, nor by assay differences, as discussed above. We are not able to explain the basis for this discrepancy; however, our observation suggests efficacy determination of GSI's in AD transgene models should be corroborated in wild type mice (see also Discussion below).

Lead optimization of the caprolactam sulfonamide enabled discovery of a novel pyrazolylazabicyclo(3.3.1) nonane sulfonamide, ELN475516 (this report, and [60]). ELN475516 demonstrated equipotent in vivo activity against $A \beta_{1-x}$ in PDAPP transgene as well as $A \beta_{x-40}$ in wild type mice, retaining favorable $123 \mathrm{X}$ APP-selective inhibition of gamma-secretase. The potency and cellular selectivity of ELN475516 compares favorably with recently disclosed GSI-953 [48] and BMS-708163 $[78,79]$, which demonstrated $45 \mathrm{X}$ and $57 \mathrm{X}$ selectivity in our hands, with $\mathrm{IC}_{50}$ values for inhibition of $\mathrm{A} \beta$ production in the SNC assay of $8.0 \mathrm{nM}$, and $1.13 \mathrm{nM}$, respectively. The novel sulfonamide inhibitors we describe exhibit all the signatures associated classical gammasecretase inhibitors: elevation of $C 99$ levels and equipotent inhibition of $A \beta 40$ and $A \beta 42$ production without affecting secreted APP levels. These properties are consistent with those reported for a novel thiophene sulfonamide gamma-secretase inhibitor, GSI-953 [48]. In binding site studies, both ELN318463 and ELN475516 were not able to displace a biotin-labeled active site binding probe in cellular extracts over a range of concentrations tested, suggesting the inhibitors bind gamma-secretase at a site distinct from the active site, 


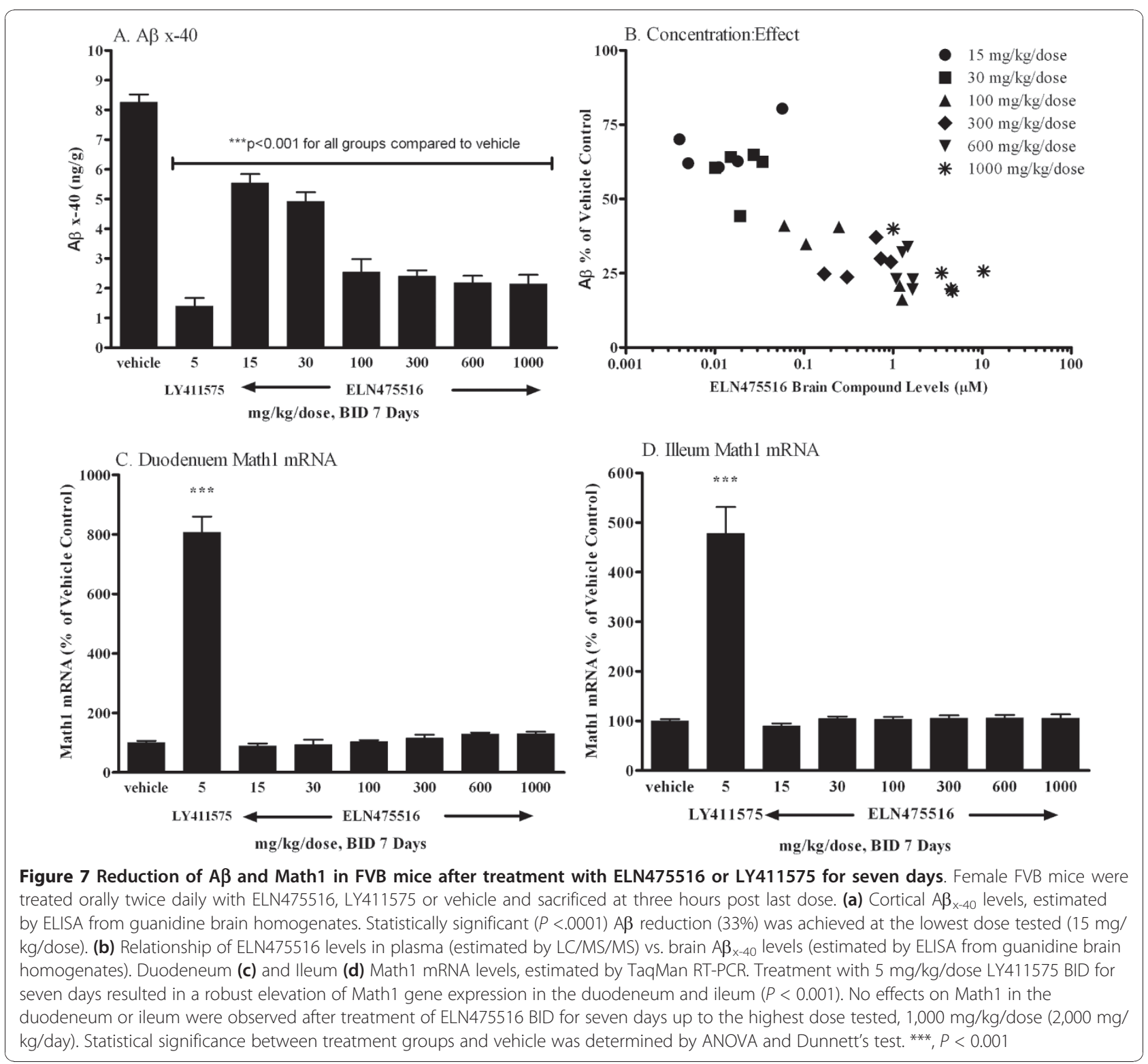

consistent with effects reported for GSI-953 [48], as well as non-transition state-based gamma-secretase inhibitors [80]. Interestingly, in the presence of exogenous APP substrate added to the extracts, we were able to detect displacement of the active site isostere at concentrations above the $\mathrm{IC}_{50}$ for $\mathrm{A} \beta$ inhibition by the compound. This novel observation suggests that occupancy of the substrate binding site on gamma-secretase by APP induces a conformational change bringing the sulfonamide binding site and isostere binding (that is, catalytic) sites in close proximity, enabling displacement of isostere by sulfonamide at supra-physiological concentrations. Although we did not test the effect of other substrates in the competitive displacement assay, it will be interesting to compare the effect, for example, of Notch substrate on displacement of active site isostere by test GSI's in future studies.

The improved selectivity of ELN475516 was tested in a mouse seven-day repeat dose model. Relative to LY411575, a reference non-selective gamma-secretase inhibitor, ELN475516 demonstrated significant reduction of brain $\mathrm{A} \beta$ at the lowest dose tested $(15 \mathrm{mg} / \mathrm{kg} /$ dose, b.i.d.), with no overt signs of toxicity at the highest dose tested $(1,000 \mathrm{mg} / \mathrm{kg} /$ dose, b.i.d.) at the end of the study, indicating an in vivo selectivity $>65$ based on dose as well as terminal compound concentration in plasma. For this study, a minimum efficacious dose was defined as that dose effecting $>25 \%$ reduction at 


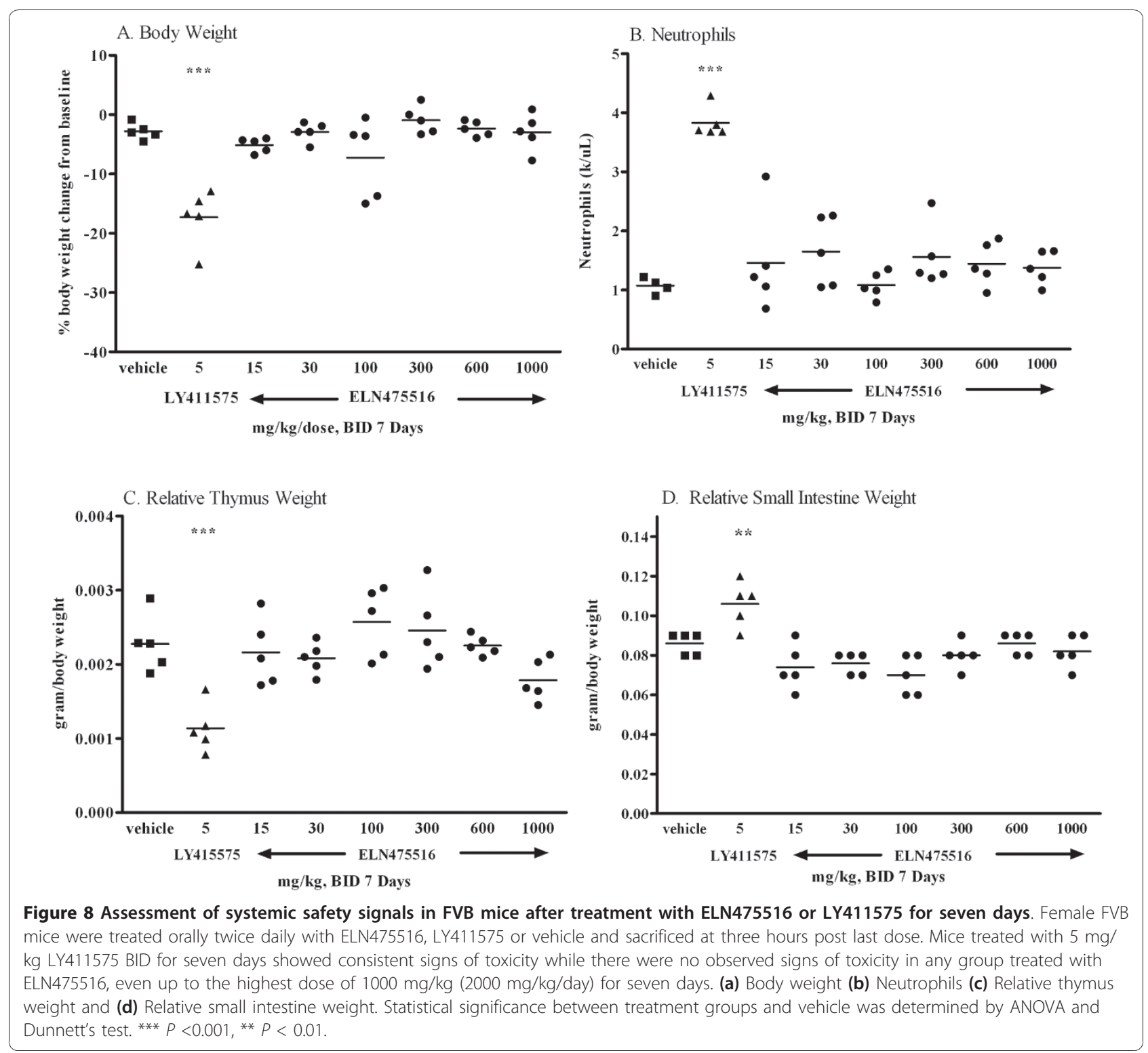

study termination (that is, three hours post last dose). Terminal plasma compound levels at the highest dose tested were $12.3 \mu \mathrm{M}$, a 17 -fold multiple over the cellular $\mathrm{IC}_{50}$ for inhibition of Notch signaling. The utility of the mouse as a model for screening of lead gammasecretase inhibitor candidates against Notch endpoints has been previously described [41]. Our studies employed the wild-type FVB strain of mice for $A \beta$ and Notch endpoints instead of transgenic AD mice as described by Hyde et al. to avoid potential transgene model specific influences on in vivo inhibitor potency against $A \beta$ endpoints. For example, substrate expression levels [81], as well as PS1 FAD mutations [59,82-84] have been demonstrated to effect a right-ward shift on in vitro potencies of gamma-secretase inhibitors. If substrate levels, or PS1 isoform contributes to in vivo potency shifts, the effect could potentially confound estimates of in vivo selectivity in an APP and/or PS1FAD transgene mouse model. Consistent with the influence of APP expression levels on inhibitor potency, we observed a $33 \%$ reduction of brain $A \beta_{x-40}$ in wt FVB mice at three hours post treatment with $30 \mathrm{mg} / \mathrm{kg}$ GSI953, compared with $5 \mathrm{mg} / \mathrm{kg}$ producing a similar magnitude effect in Tg2567 mice [48], although it is possible the observed discrepancy may be accounted for by differences in drug exposures in the target organ in FVB mice and Tg2576, or different species of $A \beta$ assayed in the different mouse models queried. 

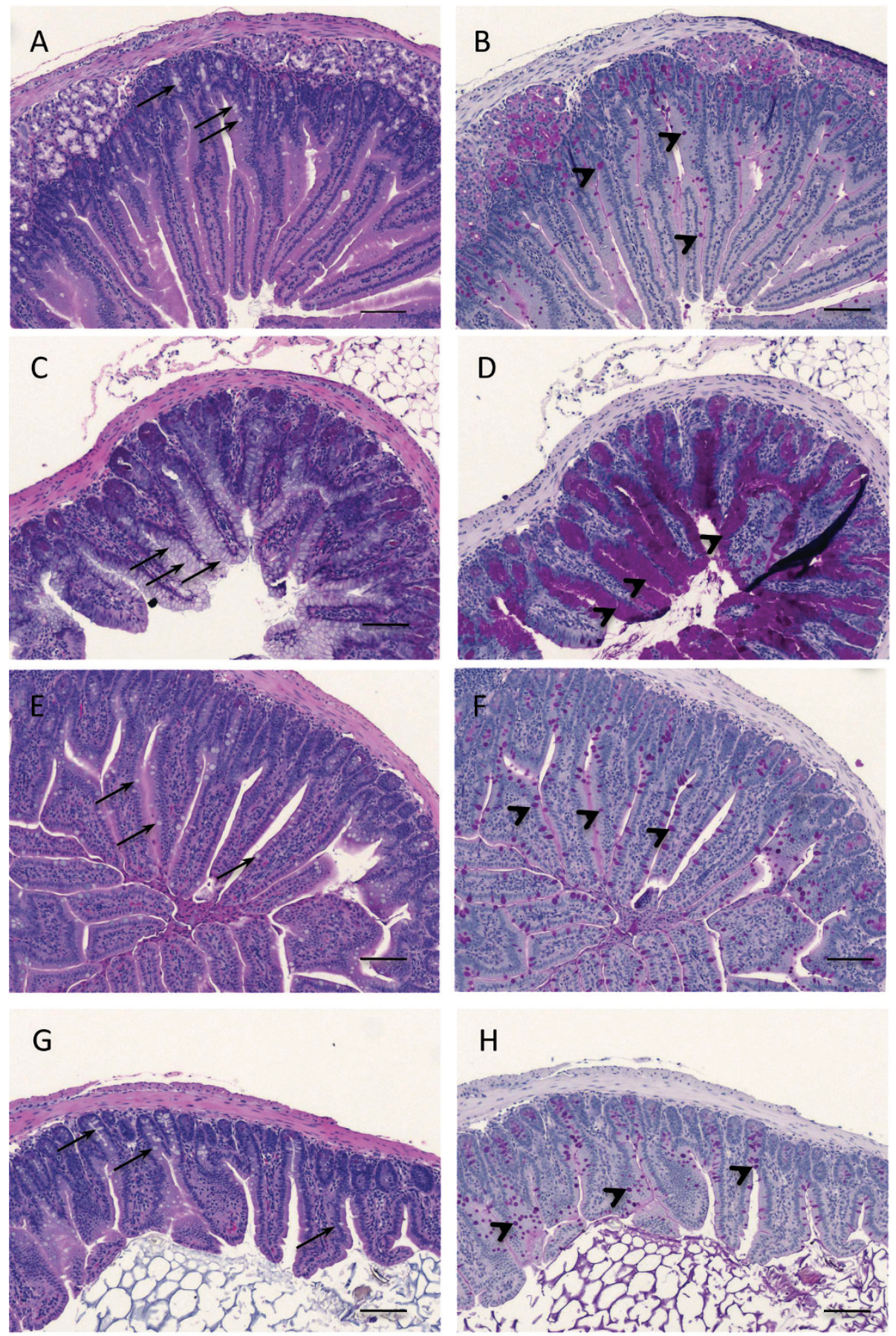

Figure 9 Photomicrographs of ileum sections (10X magnification) from mice treated seven days $\mathrm{x}$ b.i.d. with gamma-secretase inhibitors noted below. Selected sections represent the range of goblet cell hyperplasia observed in this study. In H\&E stained sections (a, c, e and $\mathbf{g}$ ), goblet cells appear as cells with clear or foamy cytoplasm (arrows) while in PAS stained sections (b, $\mathbf{d}, \mathbf{f}$ and $\mathbf{h}$ ) they appear as dark magenta stained cells (arrow heads). A normal population of goblet cells was observed in all vehicle control mice (a, b). All positive control LY411575 treated mice had a moderate increase in goblet cells $(c, d)$. There was no apparent dose-related increase in goblet cells across ELN475516 treated groups (see Table 2); among all mice in these groups, 21 had no increase in goblet cells, 8 had a questionable increase (illustrated by a single animal from $100 \mathrm{mg} / \mathrm{kg}$ dose group $\mathrm{g}, \mathrm{h}$ ). A single mouse from the $600 \mathrm{mg} / \mathrm{kg}$ dose group had a mild increase in goblet cells, which is shown for comparison purposes in panels (e and f). Scale bar $=100 \mu \mathrm{m}$. 
Table 2 Histology scores of mice following 7 days treatment

\begin{tabular}{|c|c|c|c|c|}
\hline \multirow[t]{2}{*}{ Treatment (mg/kg/dose) } & \multicolumn{2}{|c|}{ Duodenum } & \multicolumn{2}{|c|}{ Ileum } \\
\hline & \# animals affected & Mean severity score & \# animals affected & Mean severity score \\
\hline Vehicle & 0 & NA & 0 & NA \\
\hline 5 mg/kg LY411575 & $4^{*}$ & 2 & 5 & 3 \\
\hline 15 mg/kg ELN475516 & 0 & NA & 0 & NA \\
\hline 30 mg/kg ELN475516 & 0 & NA & 4 & 0.5 \\
\hline 100 mg/kg ELN475516 & 0 & NA & 2 & 1.25 \\
\hline 300 mg/kg ELN475516 & 0 & NA & 0 & NA \\
\hline 600 mg/kg ELN475516 & 0 & NA & 2 & 0.5 \\
\hline 1,000 mg/kg ELN475516 & 0 & NA & 1 & 0.5 \\
\hline
\end{tabular}

Small intestine histopathology of mice treated twice daily with the compound and doses indicated in column 1. Duodenum and ileum segments from treated mice were analyzed for cellular homeostasis by histology as indicated in methods. The number of animals affected is indicated next to the dose, as well as the mean severity score for goblet cell hyperplasia in the affected animals. Severity score rating: $0=$ no significant change, $0.5=$ questionable, $1=$ minimal, $2=$ mild, $3=$ moderate, 4 = severe ( ${ }^{*}$ tissue lost from one animal). NA indicates not applicable.

It is noteworthy that all substrate selective GSIs described to date are based on sulfonamide pharmacophore ([47,79,85-87], and this report). Indeed, a first generation aryl sulfonamide GSI, BMS299897 [10,11,88], was demonstrated to avoid Notch inhibition endpoints in the gastro-intestinal tract in a preclinical safety model [28]. Additional arylsulfonamide analogs related to BMS299897 [89], as well as aminocaprolactam sulfonamides related to ELN318463 have been described [79,90]. The APP selectivity of the sulfonamide core appears to be very sensitive to structural modifications. For example, potent and in vivo active (bicycle(4:2:1) nonane sulfamide GSI's [91,92], as well as 4-cyclohexyl sulfones [12,93] have been reported as equipotent on APP and Notch. Interestingly, despite equipotent inhibition of APP and Notch processing by gamma-secretase, sulfones are reported to be well tolerated at $3 \mathrm{mg} / \mathrm{kg}$ dose in a threemonth treatment study in the Tg2576 mouse model [14], although higher doses were not reported. In a similar vein, whereas potent piperdine containing sulfonamide GSI have also been described [90,94-97], APP selectivity has only been reported following incorporation of a pyrazole substituent into the piperdine sulfonamide core [98].

The molecular basis of sulfonamide based GSIs APP selectivity remains to be fully elucidated. We have reported that one contributor of selectivity may be the more potent inhibition of PS1 gamma-secretase compared with PS2 gamma-secretase [59] by sulfonamides. Consistent with this finding, ELN475516 is a five-fold more selective PS1 gamma-secretase inhibitor relative to PS2 gamma-secretase (unpublished). Site directed mutagenesis studies have identified select residues in PS1 which affect AICD processing from APP without affecting NICD production from Notch $[99,100]$, supporting the potential for modulating cleavage by this enzyme in a selective manner. These observations, combined with substituted cysteine accessibility mutagenesis to more precisely map inhibitor binding residues $[101,102]$, offer an avenue to further characterize the biochemical basis of APP selectivity. In summary, the in vivo selectivity of ELN475516 from a mouse seven-day safety model corroborates the improved selectivity estimated for this compound in the cellular SNC assay, confirming APP selective inhibition of gamma-secretase in vivo by this novel pyrazolylazabicyclo(3.3.1)nonane sulfonamide. ELN475156 represents a validated foundation for further lead optimization to discover APP selective second generation GSIs with improved safety and drug like properties suitable for chronic AD therapy $[60,98,103,104]$.

\section{Conclusions}

Our results showing discordance in reduction of brain $\mathrm{A} \beta$ between PDAPP and wild-type FVB mice following treatment with ELN318463 highlight the importance of evaluating GSI's for potency and selectivity in non-transgene models of Alzheimer's disease. The in vitro and in vivo selectivity of ELN475516 demonstrates that discovery of APP selective GSI's is feasible, and that APP selective GSI's offer potentially safer candidates as therapeutics for Alzheimer's disease.

\section{Additional material}

Additional File 1: Figure S1. In vitro enzyme kinetics of gammasecretase preparation on APP and Notch substrates. The results show that the in vitro assay displays Michaelis-Menten kinetics for substrate.

Additional File 2: Figure S2. Neo-epitope specificity of Notch antibody recognizing Notch Intracellular domain.

Additional File 3: Figure S3. Equipotent inhibition of $A \beta 40$ and A $\beta 42$ by gamma-secretase inhibitors in a cellular assay.

Additional File 4: Figure S4. Flow-chart of displacement assay with active-site binding affinity ligand in the presence or absence of added APP substrate plus competing sulfonamide.

Additional File 5: Figure S5. Evolution of sulfonamide structure activity relationship from caprolactam sulfonamides to fused bicyclic sulfonamides 


\section{Abbreviations}

AB: amyloid beta-peptide; AD: Alzheimer's disease; APP: amyloid precursor protein; APPsw: Swedish familial Alzheimer's disease mutant isoform of APP BACE: beta-APP cleaving enzyme; BMS299897: 2-((1R)-1-(((4-chlorophenyl) sulfonyl)(2,5-difluorophenyl)amino)ethyl)-5-fluorobenzenebutanoic acid; CHES: 2-(N-Cyclohexylamino)ethanesulfonic acid; CHO: Chinese hamster ovary; CSF: cerebrospinal fluid; CTF: carboxy-terminal fragment; DTT: dithiothreitol; DMSO: dimethyl-sulfoxide; ELISA: enzyme like immunoadsorbent assay; ELN158162: 4-Chloro-N-(3-methoxy-4-(2-(4-methyl-1,3-thiazol-5-yl)ethoxy) benzyl)-N-((3R)-2-oxoazepan-3-yl)benzenesulfonamide; ELN-318463: N-(4Bromobenzyl)-4-chloro-N-((3R)-2-oxoazepan-3-yl)benzenesulfonamide; ELN475516: 10-((4-Chlorophenyl)sulfonyl)-4,5,6,7,8,9-hexahydro-1H-4,8epiminocycloocta(c)pyrazole; FAD: familial Alzheimer's disease; GSI: gammasecretase inhibitor; HA: hemagglutnin antigen; H\&E, hematoxylin and eosin HEK, human embryonic kidney; Hes, hairy enhancer-of-split; HTS: high through-put screen; KO: knock-out, L-685,458: tert-Butyl (2S,3R,5R)-6-((S)-1((S)-1-amino-1-oxo-3-phenylpropan-2-ylamino)-4-methyl-1-oxopentan-2ylamino)-5-benzyl-3-hydroxy-6-oxo-1-phenylhexan-2-ylcarbamate; LC: liquid chromatography; mAb: monoclonal antibody; LY 411575, (S)-2-((S)-2-(3,5Difluorophenyl)-2-hydroxyacetamido)-N-((S)-5-methyl-6-oxo-6,7-dihydro-5Hdibenzo(b,d)azepin-7-yl)propanamide; MES, 2(N-Morpholino)ethanesulfonic acid; Math: mouse atonal homolog; MS: mass spectrometry; Nct: Nicastrin; NICD: Notch Intracellular domain; PAGE: polyacrylamide gel electrophoresis; PAS: periodic acid-Schiff stain; PDAPP: platelet derived growth factor promoter driven AD transgene mouse; SAPP: secreted APP; SAPPß: secreted APP product of BACE cleavage; SNC: a stable CHO cell line co-expressing APPSW, rat Notch $\triangle E$, and an NICD responsive CBF-Luciferase reporter gene; PS: presenilin; RT-PCR: reverse-transcriptase polymerase chain reaction; WGA: wheat-germ agglutnin

\section{Acknowledgements}

We thank the following individuals for their input into the work described in this report: Russel Caccavello, Karen Chen, Rick Dovey, Chip Frigon, Dionne Kobayashi, Jiping Huang, Nancy Jewett, Seymond Pon, Byron Zhao, Bud Maynard, Tracy Cole, Steve Webb, Monica Yu, Sukanto Sinha, Weiqun Liu, and in particular, Ivan Lieberburg for his support, encouragement and sage advice throughout the course of this project.

\section{Author details}

'Elan Pharmaceuticals, Inc. 180 Oyster Point Blvd., S. San Francisco, CA 94080, USA. ${ }^{2}$ Neotope Biosciences Inc., 650 Gateway Blvd., S San Francisco, CA 94080, USA.

\section{Authors' contributions}

GSB, EFB, JB, MSD, JH, SH, LHL, MNM, LM, MLN, KQ, PS, JAT, AWG, JMS, AWK, GS, MAP, SBF, and DS participated in research design. SH, AL, DLA, X-HC, MSD, TE, EG, KH, TH, JJJ, PSK, DK, RLH, ML, JM, MNM, SM, JLM, RM, MLN, HN, $L N, L R, C M S, J S, F S, B S, K T, P T, X M Y, M Y, J W$ and $Y Z$ conducted experiments. GSB, SH, EFB, AL, DLA, JB, RB, MB, X-HC, MSD, EG, JH, KH, TH, JJJ, PSK, LHL, ML, MNM, JLM, RM, LM, MLN, LN, KQ, CMS, PS, BS, JAT, XMY, YZ, AWG, JMS, AWK, DS and GS performed data analysis. GSB, SH, EFB, MB, JH, LHL, AWG, DN and DS wrote, or contributed to writing of manuscript.

\section{Competing interests}

All authors of this manuscript either were, or currently still are, employees of Elan Pharmaceuticals, Inc. at the time the studies reported in this manuscript were conducted, hold (or held) stock in Elan, and are inventors on patent filings resulting from the work described herein.

Received: 14 October 2010 Revised: 16 December 2010

Accepted: 29 December 2010 Published: 29 December 2010

\section{References}

1. Hardy J, Selkoe DJ: The amyloid hypothesis of Alzheimer's disease: progress and problems on the road to therapeutics. Science 2002, 297:353-356.

2. Selkoe DJ: Alzheimer's disease: a central role for amyloid. J Neuropathol Exp Neurol 1994, 53:438-447.

3. Selkoe DJ: Alzheimer's disease is a synaptic failure. Science 2002, 298:789-791.

4. Schenk D, Barbour R, Dunn W, Gordon G, Grajeda H, Guido T, Hu K, Huang J, Johnson-Wood K, Khan K, Kholodenko D, Lee M, Liao Z,
Lieberburg I, Motter R, Mutter L, Soriano F, Shopp G, Vasquez N, Vandevert C, Walker S, Wogulis M, Yednock T, Games D, Seubert P: Immunization with amyloid-beta attenuates Alzheimer-disease-like pathology in the PDAPP mouse. Nature 1999, 400:173-177.

5. DeMattos RB, Bales KR, Cummins DJ, Dodart JC, Paul SM, Holtzman DM: Peripheral anti-A beta antibody alters CNS and plasma A beta clearance and decreases brain A beta burden in a mouse model of Alzheimer's disease. Proc Natl Acad Sci USA 2001, 98:8850-8855.

6. Wilcock DM, DiCarlo G, Henderson D, Jackson J, Clarke K, Ugen KE, Gordon MN, Morgan D: Intracranially administered anti-Abeta antibodies reduce beta-amyloid deposition by mechanisms both independent of and associated with microglial activation. J Neurosci 2003, 23:3745-3751.

7. Oddo S, Caccamo A, Tran L, Lambert MP, Glabe CG, Klein WL, LaFerla FM: Temporal profile of amyloid-beta (Abeta) oligomerization in an in vivo model of Alzheimer disease. A link between Abeta and tau pathology. J Biol Chem 2006, 281:1599-1604.

8. Brody DL, Holtzman DM: Active and passive immunotherapy for neurodegenerative disorders. Annu Rev Neurosci 2008, 31:175-193.

9. Schenk D, Hagen M, Seubert P: Current progress in beta-amyloid immunotherapy. Curr Opin Immunol 2004, 16:599-606.

10. Anderson JJ, Holtz G, Baskin PP, Turner M, Rowe B, Wang B, Kounnas MZ, Lamb BT, Barten D, Felsenstein K, McDonald I, Srinivasan K, Munoz B, Wagner SL: Reductions in beta-amyloid concentrations in vivo by the gamma-secretase inhibitors BMS-289948 and BMS-299897. Biochem Pharmacol 2005, 69:689-698.

11. Barten DM, Guss VL, Corsa JA, Loo A, Hansel SB, Zheng M, Munoz B, Srinivasan K, Wang B, Robertson BJ, Polson CT, Wang J, Roberts SB, Hendrick JP, Anderson JJ, Loy JK, Denton R, Verdoorn TA, Smith DW, Felsenstein KM: Dynamics of \{beta\}-amyloid reductions in brain, cerebrospinal fluid, and plasma of \{beta\}-amyloid precursor protein transgenic mice treated with a \{gamma\}-secretase inhibitor. J Pharmacol Exp Ther 2005, 312:635-643.

12. Best JD, Jay MT, Otu F, Churcher I, Reilly M, Morentin-Gutierrez P, Pattison C, Harrison T, Shearman MS, Atack JR: In vivo characterization of Abeta(40) changes in brain and cerebrospinal fluid using the novel gammasecretase inhibitor $\mathrm{N}$-[cis-4-[(4-chlorophenyl)sulfonyl]-4-(2,5difluorophenyl)cyclohexyl]-1,1, 1-trifluoromethanesulfonamide (MRK-560) in the rat. J Pharmacol Exp Ther 2006, 317:786-790.

13. Best JD, Jay MT, Otu F, Ma J, Nadin A, Ellis S, Lewis HD, Pattison C, Reilly M, Harrison T, Shearman MS, Williamson TL, Atack JR: Quantitative measurement of changes in amyloid-beta(40) in the rat brain and cerebrospinal fluid following treatment with the gamma-secretase inhibitor LY-411575 [N2-[(2S)-2-(3,5-difluorophenyl)-2-hydroxyethanoyl]N1-[(7S)-5-methyl-6-ox o-6,7-dihydro-5H-dibenzo[b,d]azepin-7-yl]-Lalaninamide]. J Pharmacol Exp Ther 2005, 313:902-908.

14. Best JD, Smith DW, Reilly MA, O'Donnell R, Lewis HD, Ellis S, Wilkie N, Rosahl TW, Laroque PA, Boussiquet-Leroux C, Churcher I, Atack JR, Harrison T, Shearman MS: The novel gamma secretase inhibitor N-[cis-4[(4-chlorophenyl)sulfonyl]-4-(2,5-difluorophenyl)cyclohexyl]-1,1, 1trifluoromethanesulfonamide (MRK-560) reduces amyloid plaque deposition without evidence of notch-related pathology in the Tg2576 mouse. J Pharmacol Exp Ther 2007, 320:552-558.

15. Dovey HF, John V, Anderson JP, Chen LZ, de Saint Andrieu P, Fang LY, Freedman SB, Folmer B, Goldbach E, Holsztynska EJ, Hu KL, JohnsonWood KL, Kennedy SL, Kholodenko D, Knops JE, Latimer LH, Lee M, Liao Z, Lieberburg IM, Motter RN, Mutter LC, Nietz J, Quinn KP, Sacchi KL, Seubert PA, Shopp GM, Thorsett ED, Tung JS, Wu J, Yang S, et al: Functional gamma-secretase inhibitors reduce beta-amyloid peptide levels in brain. J Neurochem 2001, 76:173-181.

16. Lanz TA, Himes CS, Pallante G, Adams L, Yamazaki S, Amore B, Merchant KM: The gamma-secretase inhibitor N-[N-(3,5difluorophenacetyl)-L-alanyl]-S-phenylglycine t-butyl ester reduces $\mathrm{A}$ beta levels in vivo in plasma and cerebrospinal fluid in young (plaquefree) and aged (plaque-bearing) Tg2576 mice. J Pharmacol Exp Ther 2003, 305:864-871.

17. Lanz TA, Hosley JD, Adams WJ, Merchant KM: Studies of Abeta pharmacodynamics in the brain, cerebrospinal fluid, and plasma in young (plaque-free) Tg2576 mice using the gamma-secretase inhibitor N2-[(2S)-2-(3,5-difluorophenyl)-2-hydroxyethanoyl]-N1-[(7S)-5-methyl-6oxo -6,7-dihydro-5H-dibenzo[b,d]azepin-7-yl]-L-alaninamide (LY-411575). J Pharmacol Exp Ther 2004, 309:49-55. 
18. Lanz TA, Karmilowicz MJ, Wood KM, Pozdnyakov N, Du P, Piotrowski MA, Brown TM, Nolan CE, Richter KE, Finley JE, Fei Q, Ebbinghaus CF, Chen YL, Spracklin DK, Tate B, Geoghegan KF, Lau LF, Auperin DD, Schachter JB: Concentration-dependent modulation of amyloid-beta in vivo and in vitro using the gamma-secretase inhibitor, LY-450139. J Pharmacol Exp Ther 2006, 319:924-933.

19. Garcia-Alloza M, Subramanian M, Thyssen D, Borrelli LA, Fauq A, Das P, Golde TE, Hyman BT, Bacskai BJ: Existing plaques and neuritic abnormalities in APP:PS1 mice are not affected by administration of the gamma-secretase inhibitor LY-411575. Mol Neurodegener 2009, 4:19.

20. May PC, Altstiel LD, Bender MH, Boggs LN, Calligaro DO, Fuson KS, Gitter BD, Hyslop PA, Jordan WH, Li WY, Mabry TE, Mark RJ, Ni B, Nissen JS, Porter WJ, Sorgen SG, Su Y, Audia JE, Dovey HF, Games D, John V, Freedman SB, Guido T, Johnson-Wood KL, Kahn K, Latimer LH, Lieberburg IM, Seubert PA, Soriano F, Thorsett ED, et al: Marked reduction of $A \beta$ accumulation and $\beta$-amyloid plaque pathology in mice upon chronic treatment with a functional gamma-secretase inhibitor. Soc for Neurosci Abstr 2001, 27:687.1.

21. Abramowski D, Wiederhold KH, Furrer U, Jaton AL, Neuenschwander A, Runser MJ, Danner S, Reichwald J, Ammaturo D, Staab D, Stoeckli M, Rueeger H, Neumann U, Staufenbiel M: Dynamics of Abeta turnover and deposition in different beta-amyloid precursor protein transgenic mouse models following gamma-secretase inhibition. J Pharmacol Exp Ther 2008, 327:411-424.

22. Yan P, Bero AW, Cirrito JR, Xiao Q, Hu X, Wang Y, Gonzales E, Holtzman DM, Lee JM: Characterizing the appearance and growth of amyloid plaques in APP/PS1 mice. J Neurosci 2009, 29:10706-10714.

23. Comery TA, Martone RL, Aschmies S, Atchison KP, Diamantidis G, Gong X, Zhou H, Kreft AF, Pangalos MN, Sonnenberg-Reines J, Jacobsen JS, Marquis KL: Acute gamma-secretase inhibition improves contextual fear conditioning in the Tg2576 mouse model of Alzheimer's disease. J Neurosci 2005, 25:8898-8902.

24. Townsend M, Qu Y, Gray A, Wu Z, Seto T, Hutton M, Shearman MS, Middleton RE: Oral treatment with a gamma-secretase inhibitor improves long-term potentiation in a mouse model of Alzheimer's Disease. $J$ Pharmacol Exp Ther 2010, 333:110-119.

25. Churcher I, Beher D: Gamma-secretase as a therapeutic target for the treatment of Alzheimer's disease. Curr Pharm Des 2005, 11:3363-3382.

26. Garofalo AW: Patents targeting $\gamma$-secretase inhibition and modulation for the treatment of Alzheimer's disease: 2004 - 2008. Expert Opin Ther Patents 2008, 18:693-703.

27. Imbimbo BP: Therapeutic potential of gamma-secretase inhibitors and modulators. Curr Top Med Chem 2008, 8:54-61.

28. Milano J, McKay J, Dagenais C, Foster-Brown L, Pognan F, Gadient R, Jacobs RT, Zacco A, Greenberg B, Ciaccio PJ: Modulation of notch processing by gamma-secretase inhibitors causes intestinal goblet cell metaplasia and induction of genes known to specify gut secretory lineage differentiation. Toxicol Sci 2004, 82:341-358.

29. Searfoss GH, Jordan WH, Calligaro DO, Galbreath EJ, Schirtzinger LM, Berridge BR, Gao H, Higgins MA, May PC, Ryan TP: Adipsin, a biomarker of gastrointestinal toxicity mediated by a functional gamma-secretase inhibitor. J Biol Chem 2003, 278:46107-46116.

30. Wong GT, Manfra D, Poulet FM, Zhang Q, Josien H, Bara T, Engstrom L, Pinzon-Ortiz M, Fine JS, Lee HJ, Zhang L, Higgins GA, Parker EM: Chronic treatment with the gamma-secretase inhibitor LY-411,575 inhibits betaamyloid peptide production and alters lymphopoiesis and intestinal cell differentiation. J Biol Chem 2004, 279:12876-12882.

31. Fleisher AS, Raman R, Siemers ER, Becerra L, Clark CM, Dean RA, Farlow MR, Galvin JE, Peskind ER, Quinn JF, Sherzai A, Sowell BB, Aisen PS, Thal LJ: Phase 2 safety trial targeting amyloid beta production with a gammasecretase inhibitor in Alzheimer disease. Arch Neurol 2008, 65:1031-1038.

32. Siemers E, Skinner M, Dean RA, Gonzales C, Satterwhite J, Farlow M, Ness D, May PC: Safety, tolerability, and changes in amyloid beta concentrations after administration of a gamma-secretase inhibitor in volunteers. Clin Neuropharmacol 2005, 28:126-132

33. Siemers ER, Quinn JF, Kaye J, Farlow MR, Porsteinsson A, Tariot $P$, Zoulnouni P, Galvin JE, Holtzman DM, Knopman DS, Satterwhite Gonzales C, Dean RA, May PC: Effects of a gamma-secretase inhibitor in a randomized study of patients with Alzheimer disease. Neurology 2006, 66:602-604.
34. Lilly Halts Development of Semagacestat for Alzheimer's Disease Based on Preliminary Results of Phase III Clinical Trials. [http://newsroom.lilly. com/releasedetail.cfm?releaseid $=499794]$.

35. Jensen J, Pedersen EE, Galante P, Hald J, Heller RS, Ishibashi M, Kageyama R, Guillemot F, Serup P, Madsen OD: Control of endodermal endocrine development by Hes-1. Nat Genet 2000, 24:36-44.

36. Jenny M, Uhl C, Roche C, Duluc I, Guillermin V, Guillemot F, Jensen J, Kedinger M, Gradwohl G: Neurogenin3 is differentially required for endocrine cell fate specification in the intestinal and gastric epithelium. EMBO J 2002, 21:6338-6347.

37. Lee CS, Perreault N, Brestelli JE, Kaestner KH: Neurogenin 3 is essential for the proper specification of gastric enteroendocrine cells and the maintenance of gastric epithelial cell identity. Genes Dev 2002, 16:1488-1497.

38. Yang Q, Bermingham NA, Finegold MJ, Zoghbi HY: Requirement of Math1 for secretory cell lineage commitment in the mouse intestine. Science 2001, 294:2155-2158.

39. Stanger BZ, Datar R, Murtaugh LC, Melton DA: Direct regulation of intestinal fate by Notch. Proc Natl Acad Sci USA 2005, 102:12443-12448.

40. Luistro L, He W, Smith M, Packman K, Vilenchik M, Carvajal D, Roberts J, Cai J, Berkofsky-Fessler W, Hilton H, Linn M, Flohr A, Jakob-Rotne R, Jacobsen H, Glenn K, Heimbrook D, Boylan JF: Preclinical profile of a potent gamma-secretase inhibitor targeting notch signaling with in vivo efficacy and pharmacodynamic properties. Cancer Res 2009, 69:7672-7680.

41. Hyde LA, McHugh NA, Chen J, Zhang Q, Manfra D, Nomeir AA, Josien H, Bara T, Clader JW, Zhang L, Parker EM, Higgins GA: Studies to investigate the in vivo therapeutic window of the gamma-secretase inhibitor N2[(2S)-2-(3,5-difluorophenyl)-2-hydroxyethanoyl]-N1-[(7S)-5-methyl-6-oxo -6,7-dihydro-5H-dibenzo[b,d]azepin-7-yl]-L-alaninamide (LY411,575) in the CRND8 mouse. J Pharmacol Exp Ther 2006, 319:1133-1143.

42. Real PJ, Tosello V, Palomero T, Castillo M, Hernando E, de Stanchina E, Sulis ML, Barnes K, Sawai C, Homminga I, Meijerink J, Aifantis I, Basso G, Cordon-Cardo C, Ai W, Ferrando A: Gamma-secretase inhibitors reverse glucocorticoid resistance in T cell acute lymphoblastic leukemia. Nat Med 2009, 15:50-58.

43. Eriksen JL, Sagi SA, Smith TE, Weggen S, Das P, McLendon DC, Ozols W Jessing KW, Zavitz KH, Koo EH, Golde TE: NSAIDs and enantiomers of flurbiprofen target gamma-secretase and lower Abeta 42 in vivo. J Clin Invest 2003, 112:440-449.

44. Weggen S, Eriksen JL, Das P, Sagi SA, Wang R, Pietrzik CU, Findlay KA, Smith TE, Murphy MP, Bulter T, Kang DE, Marquez-Sterling N, Golde TE, Koo EH: A subset of NSAIDs lower amyloidogenic Abeta42 independently of cyclooxygenase activity. Nature 2001, 414:212-216.

45. Weggen S, Eriksen JL, Sagi SA, Pietrzik CU, Ozols V, Fauq A, Golde TE, Koo EH: Evidence that nonsteroidal anti-inflammatory drugs decrease amyloid beta 42 production by direct modulation of gamma-secretase activity. J Biol Chem 2003, 278:31831-31837.

46. Olson RE, Albright CF: Recent progress in the medicinal chemistry of gamma-secretase inhibitors. Curr Top Med Chem 2008, 8:17-33.

47. Cole DC, Stock JR, Kreft AF, Antane M, Aschmies SH, Atchison KP, Casebier DS, Comery TA, Diamantidis G, Ellingboe JW, Harrison BL, Hu Y, Jin M, Kubrak DM, Lu P, Mann CW, Martone RL, Moore WJ, Oganesian A Riddell DR, Sonnenberg-Reines J, Sun SC, Wagner E, Wang Z, Woller KR, Xu Z, Zhou H, Jacobsen JS: (S)-N-(5-Chlorothiophene-2-sulfonyl)-beta, beta-diethylalaninol a Notch-1-sparing gamma-secretase inhibitor. Bioorg Med Chem Lett 2009, 19:926-929.

48. Martone RL, Zhou H, Atchison K, Comery T, Xu JZ, Huang X, Gong X, Jin M, Kreft A, Harrison B, Mayer SC, Aschmies S, Gonzales C, Zaleska MM, Riddell DR, Wagner E, Lu P, Sun SC, Sonnenberg-Reines J, Oganesian A, Adkins K, Leach MW, Clarke DW, Huryn D, Abou-Gharbia M, Magolda R, Bard J, Frick G, Raje S, Forlow SB, et al: Begacestat (GSI-953): a novel, selective thiophene sulfonamide inhibitor of amyloid precursor protein gamma-secretase for the treatment of Alzheimer's disease. J Pharmacol Exp Ther 2009, 331:598-608.

49. Green RC, Schneider LS, Amato DA, Beelen AP, Wilcock G, Swabb EA, Zavitz KH, Tarenflurbil Phase 3 Study G: Effect of tarenflurbil on cognitive decline and activities of daily living in patients with mild Alzheimer disease: a randomized controlled trial. JAMA 2009, 302:2557-2564.

50. Hendrix SB, Wilcock GK: What we have learned from the Myriad trials. J Nutr Health Aging 2009, 13:362-364. 
51. Eisai to Resume Clinical Study to Evaluate E2012 as a Potential Next Generation Alzheimer's Disease Treatment. [http://www.eisai.co.jp/enews/ enews200818.html].

52. Pissarnitski D: Advances in gamma-secretase modulation. Curr Opin Drug Discov Devel 2007, 10:392-402.

53. Imbimbo BP, Hutter-Paier B, Villetti G, Facchinetti F, Cenacchi V, Volta R, Lanzillotta A, Pizzi M, Windisch M: CHF5074, a novel gamma-secretase modulator, attenuates brain beta-amyloid pathology and learning deficit in a mouse model of Alzheimer's disease. Br J Pharmacol 2009, 156:982-993

54. Shelton CC, Zhu L, Chau D, Yang L, Wang R, Djaballah H, Zheng H, Li YM: Modulation of gamma-secretase specificity using small molecule allosteric inhibitors. Proc Natl Acad Sci USA 2009, 106:20228-20233.

55. Kounnas MZ, Danks AM, Cheng S, Tyree C, Ackerman E, Zhang X, Ahn K, Nguyen P, Comer D, Mao L, Yu C, Pleynet D, Digregorio PJ, Velicelebi G, Stauderman KA, Comer WT, Mobley WC, Li YM, Sisodia SS, Tanzi RE, Wagner SL: Modulation of gamma-secretase reduces beta-amyloid deposition in a transgenic mouse model of Alzheimer's disease. Neuron 2010, 67:769-780.

56. Fraering $P C$, Ye W, LaVoie MJ, Ostaszewski BL, Selkoe DJ, Wolfe MS: gamma-Secretase substrate selectivity can be modulated directly via interaction with a nucleotide-binding site. J Biol Chem 2005, 280:41987-41996.

57. Netzer WJ, Dou F, Cai D, Veach D, Jean S, Li Y, Bornmann WG, Clarkson B, $\mathrm{Xu} \mathrm{H}$, Greengard P: Gleevec inhibits beta-amyloid production but not Notch cleavage. Proc Natl Acad Sci USA 2003, 100:12444-12449.

58. He G, Luo W, Li P, Remmers C, Netzer WJ, Hendrick J, Bettayeb K, Flajolet M, Gorelick F, Wennogle LP, Greengard P: Gamma-secretase activating protein is a therapeutic target for Alzheimer's disease. Nature 2010, 467:95-98

59. Zhao B, Yu M, Neitzel M, Marugg J, Jagodzinski J, Lee M, Hu K, Schenk D, Yednock T, Basi G: Identification of gamma-secretase inhibitor potency determinants on presenilin. J Biol Chem 2008, 283:2927-2938.

60. Mattson MN, Neitzel ML, Quincy DA, Semko CM, Garofalo AW, Keim PS, Konradi AW, Pleiss MA, Sham HL, Brigham EF, Goldbach EG, Zhang H, Sauer JM, Basi GS: Discovery of sulfonamide-pyrazole gamma-secretase inhibitors. Bioorg Med Chem Lett 2010, 20:2148-2150.

61. Sinha S, Anderson JP, Barbour R, Basi GS, Caccavello R, Davis D, Doan M, Dovey HF, Frigon N, Hong J, Jacobson-Croak K, Jewett N, Keim P, Knops J, Lieberburg I, Power M, Tan H, Tatsuno G, Tung J, Schenk D, Seubert P Suomensaari SM, Wang S, Walker D, Zhao J, McConlogue L, John V: Purification and cloning of amyloid precursor protein beta-secretase from human brain. Nature 1999, 402:537-540.

62. Kimberly WT, Esler WP, Ye W, Ostaszewski BL, Gao J, Diehl T, Selkoe DJ, Wolfe MS: Notch and the amyloid precursor protein are cleaved by similar gamma-secretase(s). Biochemistry 2003, 42:137-144.

63. Hsieh JJ, Henkel T, Salmon P, Robey E, Peterson MG, Hayward SD: Truncated mammalian Notch1 activates CBF1/RBPJk-repressed genes by a mechanism resembling that of Epstein-Barr virus EBNA2. Mol Cell Biol 1996, 16:952-959.

64. Shawber C, Nofziger D, Hsieh JJ, Lindsell C, Bogler O, Hayward D, Weinmaster G: Notch signaling inhibits muscle cell differentiation through a CBF1-independent pathway. Development 1996, 122:3765-3773.

65. Johnson-Wood K, Lee M, Motter R, Hu K, Gordon G, Barbour R, Khan K, Gordon M, Tan H, Games D, Lieberburg I, Schenk D, Seubert P, McConlogue L: Amyloid precursor protein processing and A beta42 deposition in a transgenic mouse model of Alzheimer disease. Proc Natl Acad Sci USA 1997, 94:1550-1555.

66. Games D, Adams D, Alessandrini R, Barbour R, Berthelette P, Blackwell C, Carr T, Clemens J, Donaldson T, Gillespie F, et al: Alzheimer-type neuropathology in transgenic mice overexpressing V717F beta-amyloid precursor protein. Nature 1995, 373:523-527.

67. Citron M, Oltersdorf T, Haass C, McConlogue L, Hung AY, Seubert P, VigoPelfrey C, Lieberburg I, Selkoe DJ: Mutation of the beta-amyloid precursor protein in familial Alzheimer's disease increases beta-protein production. Nature 1992, 360:672-674

68. Seubert P, Oltersdorf T, Lee MG, Barbour R, Blomquist C, Davis DL, Bryant K, Fritz LC, Galasko D, Thal LJ, et al: Secretion of beta-amyloid precursor protein cleaved at the amino terminus of the beta-amyloid peptide. Nature 1993, 361:260-263.
69. Beher D, Fricker M, Nadin A, Clarke EE, Wrigley JD, Li YM, Culvenor JG, Masters $\mathrm{CL}$, Harrison $\mathrm{T}$, Shearman MS: In vitro characterization of the presenilin-dependent gamma-secretase complex using a novel affinity ligand. Biochemistry 2003, 42:8133-8142.

70. Fraering PC, LaVoie MJ, Ye W, Ostaszewski BL, Kimberly WT, Selkoe DJ, Wolfe MS: Detergent-dependent dissociation of active gamma-secretase reveals an interaction between Pen-2 and PS1-NTF and offers a model for subunit organization within the complex. Biochemistry 2004, 43:323-333.

71. Brou C, Logeat F, Gupta N, Bessia C, LeBail O, Doedens JR, Cumano A, Roux $P$, Black RA, Israel A: A novel proteolytic cleavage involved in Notch signaling: the role of the disintegrin-metalloprotease TACE. Mol Cell 2000, 5:207-216.

72. Fortini ME: Notch and presenilin: a proteolytic mechanism emerges. Curr Opin Cell Biol 2001, 13:627-634.

73. Mumm JS, Schroeter EH, Saxena MT, Griesemer A, Tian X, Pan DJ, Ray WJ, Kopan R: A ligand-induced extracellular cleavage regulates gammasecretase-like proteolytic activation of Notch1. Mol Cell 2000, 5:197-206.

74. Nishitomi K, Sakaguchi G, Horikoshi Y, Gray AJ, Maeda M, Hirata-Fukae C, Becker AG, Hosono M, Sakaguchi I, Minami SS, Nakajima Y, Li HF, Takeyama C, Kihara T, Ota A, Wong PC, Aisen PS, Kato A, Kinoshita N, Matsuoka Y: BACE1 inhibition reduces endogenous Abeta and alters APP processing in wild-type mice. J Neurochem 2006, 99:1555-1563.

75. van Es JH, van Gijn ME, Riccio O, van den Born M, Vooijs M, Begthel H, Cozijnsen M, Robine S, Winton DJ, Radtke F, Clevers H: Notch/gammasecretase inhibition turns proliferative cells in intestinal crypts and adenomas into goblet cells. Nature 2005, 435:959-963.

76. Schroeter S, Brigham EF, Motter R, Nishioka C, Guido T, Kahn K, Kholodenko D, Tanaka P, Soriano F, Quinn KP, Goldbach E, Games D, Ness D: APP-selective gamma secretase inhibitor ELND006 effects on brain parenchymal and vascular amyloid beta in the PDAPP mouse model of Alzheimer's Disease (P3-321). Supplement to Alzheimer's and Dementia; International Conference on Alzheimer's Disease, Honolulu, Hawaii Alzheimer's Association; 2010, S546.

77. Berezovska O, Jack C, McLean P, Aster JC, Hicks C, Xia W, Wolfe MS, Kimberly WT, Weinmaster G, Selkoe DJ, Hyman BT: Aspartate mutations in presenilin and gamma-secretase inhibitors both impair notch1 proteolysis and nuclear translocation with relative preservation of notch1 signaling. J Neurochem 2000, 75:583-593.

78. Albright CF, Dockens R, Olson RE, Meredith JE, Siemmon R, Lentz K, J W Denton R, Pilcher G, Zaczek R: BMS-708163, a potent and selective gsecretase inhibitor, decreases CSF Ab at safe and tolerable doses in animals, and humans. International Conference on Alzheimer's Disease Chicago: Alzheimer's Association; 2008, HT-01-05.

79. Gillman KW, Starrett JE, Parker MF, Xie K, Bronson JJ, Marcin LR, McElhone KE, Bergstrom CP, Mate RA, Williams R, Meredith JE, Burton CR, Barten DM, Toyn JH, Roberts SB, Lentz KA, Houston JG, Zaczek R, Albright CF, Decicco CP, Macor JE, Olson RE: Discovery and Evaluation of BMS-708163, a Potent, Selective and Orally Bioavailable $\mathrm{Y}$-Secretase Inhibitor. ACS Medicinal Chemistry Letters 2010, 1:120-124.

80. Tian G, Ghanekar SV, Aharony D, Shenvi AB, Jacobs RT, Liu X, Greenberg BD: The mechanism of gamma-secretase: multiple inhibitor binding sites for transition state analogs and small molecule inhibitors. J Biol Chem 2003, 278:28968-28975.

81. Burton CR, Meredith JE, Barten DM, Goldstein ME, Krause CM, Kieras CJ, Sisk L, Iben LG, Polson C, Thompson MW, Lin XA, Corsa J, Fiedler T, Pierdomenico M, Cao Y, Roach AH, Cantone JL, Ford MJ, Drexler DM, Olson RE, Yang MG, Bergstrom CP, McElhone KE, Bronson JJ, Macor JE, Blat Y, Grafstrom RH, Stern AM, Seiffert DA, Zaczek R, et al: The amyloidbeta rise and gamma-secretase inhibitor potency depend on the level of substrate expression. J Biol Chem 2008, 283:22992-23003.

82. Czirr E, Leuchtenberger S, Dorner-Ciossek C, Schneider A, Jucker M, Koo EH, Pietrzik CU, Baumann K, Weggen S: Insensitivity to Abeta42-lowering nonsteroidal anti-inflammatory drugs and gamma-secretase inhibitors is common among aggressive presenilin-1 mutations. J Biol Chem 2007, 282:24504-24513.

83. Ikeuchi T, Dolios G, Kim SH, Wang R, Sisodia SS: Familial Alzheimer disease-linked presenilin 1 variants enhance production of both Abeta 1-40 and Abeta 1-42 peptides that are only partially sensitive to a potent aspartyl protease transition state inhibitor of "gamma-secretase". J Biol Chem 2003, 278:7010-7018. 
84. Xia W, Ostaszewski BL, Kimberly WT, Rahmati T, Moore CL, Wolfe MS, Selkoe DJ: FAD mutations in presenilin-1 or amyloid precursor protein decrease the efficacy of a gamma-secretase inhibitor: evidence for direct involvement of PS1 in the gamma-secretase cleavage complex. Neurobiol Dis 2000, 7:673-681.

85. Kreft A, Harrison B, Aschmies S, Atchison K, Casebier D, Cole DC, Diamantidis G, Ellingboe J, Hauze D, Hu Y, Huryn D, Jin M, Kubrak D, Lu P, Lundquist J, Mann C, Martone R, Moore W, Oganesian A, Porte A, Riddell DR, Sonnenberg-Reines J, Stock JR, Sun SC, Wagner E, Woller K, $\mathrm{Xu} Z$ Z, Zhou H, Steven Jacobsen J: Discovery of a novel series of Notchsparing gamma-secretase inhibitors. Bioorg Med Chem Lett 2008, 18:4232-4236.

86. Mayer SC, Kreft AF, Harrison B, Abou-Gharbia M, Antane M, Aschmies S, Atchison K, Chlenov M, Cole DC, Comery T, Diamantidis G, Ellingboe J, Fan K, Galante R, Gonzales C, Ho DM, Hoke ME, Hu Y, Huryn D, Jain U, Jin M, Kremer K, Kubrak D, Lin M, Lu P, Magolda R, Martone R, Moore W, Oganesian A, Pangalos MN, et al: Discovery of begacestat, a Notch-1sparing gamma-secretase inhibitor for the treatment of Alzheimer's disease. J Med Chem 2008, 51:7348-7351.

87. Pu J, Kreft AF, Aschmies SH, Atchison KP, Berkowitz J, Caggiano TJ, Chlenov M, Diamantidis G, Harrison BL, Hu Y, Huryn D, Steven Jacobsen J, Jin M, Lipinski K, Lu P, Martone RL, Morris K, Sonnenberg-Reines J, Riddell DR, Sabalski J, Sun SC, Wagner E, Wang Y, Xu Z, Zhou H, Resnick L: Synthesis and structure-activity relationship of a novel series of heterocyclic sulfonamide gamma-secretase inhibitors. Bioorg Med Chem 2009, 17:4708-4717.

88. Novel sulfonamide compounds and uses thereof. Patent PCT/US00// 04560.. [http://ip.com/patent/US6967196].

89. Parker MF, Barten DM, Bergstrom CP, Bronson JJ, Corsa JA, Deshpande MS, Felsenstein KM, Guss VL, Hansel SB, Johnson G, Keavy DJ, Lau WY, Mock J, Prasad CV, Polson CT, Sloan CP, Smith DW, Wallace OB, Wang HH, Williams A, Zheng M: N-(5-chloro-2-(hydroxymethyl)-N-alkylarylsulfonamides as gamma-secretase inhibitors. Bioorg Med Chem Lett 2007, 17:4432-4436.

90. Josien H, Bara T, Rajagopalan M, Asberom T, Clader JW, Favreau L, Greenlee WJ, Hyde LA, Nomeir AA, Parker EM, Pissarnitski DA, Song L, Wong GT, Zhang L, Zhang Q, Zhao Z: Small conformationally restricted piperidine $\mathrm{N}$-arylsulfonamides as orally active gamma-secretase inhibitors. Bioorg Med Chem Lett 2007, 17:5330-5335.

91. Keown LE, Collins I, Cooper LC, Harrison T, Madin A, Mistry J, Reilly M, Shaimi M, Welch CJ, Clarke EE, Lewis HD, Wrigley JD, Best JD, Murray F, Shearman MS: Novel orally bioavailable gamma-secretase inhibitors with excellent in vivo activity. J Med Chem 2009, 52:3441-3444.

92. Sparey T, Beher D, Best J, Biba M, Castro JL, Clarke E, Hannam J, Harrison T, Lewis H, Madin A, Shearman M, Sohal B, Tsou N, Welch C, Wrigley J: Cyclic sulfamide gamma-secretase inhibitors. Bioorg Med Chem Lett 2005, 15:4212-4216.

93. Churcher I, Beher D, Best JD, Castro JL, Clarke EE, Gentry A, Harrison T, Hitzel L, Kay E, Kerrad S, Lewis HD, Morentin-Gutierrez P, Mortishire-Smith R, Oakley PJ, Reilly M, Shaw DE, Shearman MS, Teall MR, Williams S, Wrigley JD: 4-substituted cyclohexyl sulfones as potent, orally active gamma-secretase inhibitors. Bioorg Med Chem Lett 2006, 16:280-284.

94. Asberom T, Zhao Z, Bara TA, Clader JW, Greenlee WJ, Hyde LA, Josien HB, Li W, McPhail AT, Nomeir AA, Parker EM, Rajagopalan M, Song L, Wong GT, Zhang L, Zhang Q, Pissarnitski DA: Discovery of gamma-secretase inhibitors efficacious in a transgenic animal model of Alzheimer's disease. Bioorg Med Chem Lett 2007, 17:511-516.

95. Gundersen E, Fan K, Haas K, Huryn D, Steven Jacobsen J, Kreft A, Martone R, Mayer S, Sonnenberg-Reines J, Sun SC, Zhou H: Molecular-modeling based design, synthesis, and activity of substituted piperidines as gammasecretase inhibitors. Bioorg Med Chem Lett 2005, 15:1891-1894.

96. Li H, Asberom T, Bara TA, Clader JW, Greenlee WJ, Josien HB, McBriar MD, Nomeir A, Pissarnitski DA, Rajagopalan M, Xu R, Zhao Z, Song L, Zhang L: Discovery of 2,4,6-trisubstituted N-arylsulfonyl piperidines as gammasecretase inhibitors. Bioorg Med Chem Lett 2007, 17:6290-6294.

97. Pissarnitski DA, Asberom T, Bara TA, Buevich AV, Clader JW, Greenlee WJ, Guzik HS, Josien HB, Li W, McEwan M, McKittrick BA, Nechuta TL, Parker EM, Sinning L, Smith EM, Song L, Vaccaro HA, Voigt JH, Zhang L, Zhang Q, Zhao Z: 2,6-Disubstituted $\mathrm{N}$-arylsulfonyl piperidines as gamma-secretase inhibitors. Bioorg Med Chem Lett 2007, 17:57-62.
98. Ye XM, Konradi AW, Smith J, Xu YZ, Dressen D, Garofalo AW, Marugg J, Sham HL, Truong A, Jagodzinski J, Pleiss M, Zhang H, Goldbach E, Sauer JM, Brigham E, Bova M, Basi GS: Discovery of a novel sulfonamidepyrazolopiperidine series as potent and efficacious gamma-secretase inhibitors. Bioorg Med Chem Lett 2010, 20:2195-2199.

99. Walker ES, Martinez M, Brunkan AL, Goate A: Presenilin 2 familial Alzheimer's disease mutations result in partial loss of function and dramatic changes in Abeta 42/40 ratios. J Neurochem 2005, 92:294-301.

100. Tolia A, Horre K, De Strooper B: Transmembrane domain 9 of presenilin determines the dynamic conformation of the catalytic site of gammasecretase. J Biol Chem 2008, 283:19793-19803.

101. Sato C, Morohashi Y, Tomita T, Iwatsubo T: Structure of the catalytic pore of gamma-secretase probed by the accessibility of substituted cysteines. J Neurosci 2006, 26:12081-12088.

102. Tolia A, Chavez-Gutierrez L, De Strooper B: Contribution of presenilin transmembrane domains 6 and 7 to a water-containing cavity in the gamma-secretase complex. J Biol Chem 2006, 281:27633-27642.

103. Bowers S, Probst GD, Truong AP, Hom RK, Konradi AW, Sham HL, Garofalo AW, Wong K, Goldbach E, Quinn KP, Sauer JM, Wallace W, Nguyen L, Hemphill SS, Bova MP, Basi GS: N-Bridged bicyclic sulfonamides as inhibitors of gamma-secretase. Bioorg Med Chem Lett 2009, 19:6952-6956.

104. Truong AP, Aubele DL, Probst GD, Neitzel ML, Semko CM, Bowers S, Dressen D, Hom RK, Konradi AW, Sham HL, Garofalo AW, Keim PS, Wu J, Dappen MS, Wong K, Goldbach E, Quinn KP, Sauer JM, Brigham EF, Wallace W, Nguyen L, Hemphill SS, Bova MP, Basi G: Design, synthesis, and structure-activity relationship of novel orally efficacious pyrazole/ sulfonamide based dihydroquinoline gamma-secretase inhibitors. Bioorg Med Chem Lett 2009, 19:4920-4923.

doi:10.1186/alzrt60

Cite this article as: Basi et al: Amyloid precursor protein selective gamma-secretase inhibitors for treatment of Alzheimer's disease. Alzheimer's Research \& Therapy 2010 2:36.

\section{Submit your next manuscript to BioMed Central and take full advantage of:}

- Convenient online submission

- Thorough peer review

- No space constraints or color figure charges

- Immediate publication on acceptance

- Inclusion in PubMed, CAS, Scopus and Google Scholar

- Research which is freely available for redistribution 